\title{
The legacy of early radiolarian taxonomists, with a focus on the species published by early German workers
}

\author{
DAVID LAZARUS \\ Museum für Naturkunde, Invalidenstrasse 43, 10115 Berlin, Germany \\ *(e-mail: david.lazarus@mfn-berlin.de)
}

\begin{abstract}
Approximately one-third of the c. 1200 polycystine radiolarian names currently recognized as valid in deep-sea research (Cenozoic sediments and plankton) come from the first century of taxonomic studies (c. 1840-1930). German scientists dominated early research on radiolarian biology and taxonomy. C. G. Ehrenberg's initial work was followed by E. Haeckel's mammoth monographic works, particularly his Challenger report. Other important early workers were D. Rüst on Mesozoic and Palaeozoic forms and A. Popofsky on plankton and sediment materials, with smaller contributions by J. Müller, E. Stöhr, F. Dreyer and H. Mast. Excluding Haeckel, these workers together published over 2000 species names. A fraction $(5-25 \%)$ of these names are still used today in deep-sea research, with a tendency for more prolific authors to have higher modern usage rates. Haeckel's legacy is different. He published over 5000 species names, but only a few percent are still used. The reasons for his species names no longer being used seem to include both factors common to disuse of names from other early authors (inadequate text descriptions, poor or absent illustration, no preserved original materials) but also due to substantial duplication of species and genus names, created by imposition of a partially artificial high level taxonomy. Based on Haeckel's own writings and by analogy to other parts of Haeckel's work, it is suggested that Haeckel's desire to discover and show evolutionary relationships lay behind this flawed approach to taxonomy. J. Micropalaeontol. 33(1): 3-19, January 2014.
\end{abstract}

KEYWORDS: systematics, plankton, microfossils, history of science, Ehrenberg, Haeckel

\section{INTRODUCTION}

All science is incremental in that it builds on past work. In micropalaeontology an early foundation of taxonomy and basic biological study has been needed to enable the use of microfossils as tools to understand geological processes, determine age or to study the mechanisms of evolution. While for most microfossil groups this foundation work has been developed more or less continuously over a period of 150 years, radiolarian research has had a less uniform path of development. After an early period of extensive study, research activity declined in the first part of the twentieth century, only increasing again, gradually, in a 'modern phase' that began in the 1960s and continues to the present (Lazarus, 2005). Thus, many questions and themes that were explored and largely resolved earlier in the study of other microfossil groups are still very much active areas of radiolarian research today. One of these is the taxonomic legacy of early researchers. Early students of radiolaria published thousands of species names and erected many, partially incompatible higher-level taxonomies to contain them. Because biological knowledge was (and is still) very limited, these early taxonomic efforts were at best provisional. Modern researchers have been confronted with the conflicting demands of resolving primary problems with taxonomy and nomenclature on the one hand, and using radiolarians in applied research on the other. While taxonomic problems are far from being fully resolved, much progress has been made, with revisions of numerous smaller groups of radiolarian taxa, e.g. species in single or in closely related genera (e.g. Nigrini, 1977; Sanfilippo et al., 1985; Lombari \& Lazarus, 1988; Sanfilippo \& Caulet, 1998). Nonetheless, much still needs to be done, and it is appropriate to review the primary taxonomic legacy with which we currently work, and that we attempt to revise. This paper provides a summary of this prior taxonomic work on fossilizable radiolaria (i.e. Polycystinea). Given that, for applied work in micropalaeontology, species are by far the most important taxonomic units, this review will mostly be about the species level. In addition to purely scientific analysis of this taxonomy, this paper will also summarize what is known about some of the early taxonomists themselves, since scientific results are always to some degree influenced by the scientists carrying out the work and, to the author's knowledge, no modern treatment exists for the majority of these workers. Rather than attempt to review all early workers, I will concentrate on early German workers, as the large majority of early scientific study of radiolarians was carried out by German workers, whether measured by number of researchers, or number of species described. Other early radiolarian workers will be mentioned primarily only by comparison with their German counterparts.

\section{IODP'S TAXONOMIC NAME LIST (TNL)}

The most important legacies of early taxonomic work are the species descriptions, at least in so far as these descriptions are recognized today as valid, and are used in modern research. Comprehensive catalogues of current radiolarian species taxonomy are not yet available, making a full evaluation of early species descriptions difficult. Recently, however, a reasonably comprehensive compilation and, for species names employed in the deep-sea drilling programmes, evaluation (valid, synonym, etc.) has been made which will be used here to provide numerical data on species taxonomy (Lazarus et al., 2012). This list of radiolarian species names was created by a team of workers as part of the Integrated Ocean Drilling Program's (IODP) efforts to improve data management and multiplatform database integration (Lazarus et al., 2012). This 'taxonomic name list', or TNL, contains over 1600 valid species names and, in all, over 17000 radiolarian species names or name variants. 
Names in the TNL come from four distinct sources. First, it contains all radiolarian names found by IODP database specialists both in IODP publications and in an earlier phase of deep-sea ocean drilling (ODP). This also includes name variants - misspellings, questionable identifications and the like. Name variants are flagged as non-valid species in the TNL and are linked as synonyms to the correct name forms, but the reason for synonymy (e.g. objective junior synonym v. misspelling) is given only in unstructured notes, and cannot be summarized easily in searches. This tends to inflate record numbers to some extent in summary counts, though presumably to a fairly uniform degree for all record subsets. Second, it contains all the radiolarian names held in the Neptune database (Lazarus, 1994; Spencer-Cervato, 1999), including names both from ODP and from the earliest phase of deep sea drilling - DSDP, with additional names added directly from the deep-sea drilling literature. This list too includes variant names as well as base names. Third, the TNL contains all names compiled from the plankton literature and listed as valid in the WoRMS marine species database (Lazarus et al., 2011). This list of living species, while not fully complete, attempts to list all plankton taxa described as valid and used in at least some modern publications, although the validity of some of these names is still not clear (Boltovskoy et al., 2010). These modern research sources provide more than 4000 names and name variants (questionable identifications, cf. and other open-nomenclature forms). Fourth, it holds all validly published radiolarian species names compiled directly from the original literature (fairly complete up to c. 1970 , somewhat less so afterwards) as part of two parallel, as yet unpublished radiolarian taxonomic database efforts (RadWorld, by J.-P. Caulet, C. Nigrini \& A. Sanfilippo; and an unnamed database by N. Suzuki).

The IODP radiolarian TNL evaluates the taxonomic status for all names encountered in any of the source databases of modern deep-sea drilling research, but largely does not attempt to evaluate the status of any names not recorded in the history of deep-sea drilling research publication. This combination of names - from modern deep-sea drilling research literature and from early taxonomic literature - provides an opportunity to estimate the relative contributions of different authors and historical time intervals to the development of radiolarian species taxonomy, and also to assess how many of the species names published by early taxonomists are actually employed in modern research. This assessment is limited to the dominantly Cenozoic age of typical deep-sea drilling sediment recovery (Lazarus, 2006) but, as the majority of the early taxonomists also worked on Cenozoic material, this is not a major problem.

\section{THE NUMERICAL DEVELOPMENT OF RADIOLARIAN SPECIES TAXONOMY}

One of the first aspects that need to be determined is the distribution in historical time of radiolarian species taxonomic descriptions. This provides the context needed to judge how generally important early work has been. Figures $1 \mathrm{a}-\mathrm{c}$ show the numbers of species described v. year; for just those species that are used in deep-sea drilling publications; and for species that are considered valid in the TNL. A clear bimodal pattern exists in all three figures, with an early period of activity between $c$. 1850 and 1910 , a period of rather low rates of publication between c. 1910 and 1960, and renewed taxonomic output since
1960 (the database is not fully updated with papers published in the last few years and this, together with a decline in the number of IODP 'palaeoceanographic' legs, explains the low values in the 2000-2010 bin). There are two other obvious features in these plots. One is the enormous peak of total species descriptions in the 1885-1890 bin (Fig. 1a). This is due almost entirely to Haeckel's enormous Challenger monograph (discussed below). The other is the different weights of the early v. recent phases apparent when comparing the figures. In the total published species graph (Fig. 1a) the early phase and modern phase of taxonomic work contribute nearly equally to the total numbers of species descriptions even when excluding the 1885-1890 peak. By contrast, the modern phase of species descriptions contributes significantly more species when measured either by those names actually used in deep-sea drilling research (Fig. 1b), or among Cenozoic-Recent names considered to be valid (445 such names published that are older than 1920 v. 818 names between 1934 to the Recent - Fig. 1c).

\section{MAJOR EARLY AUTHORS OF RADIOLARIAN SPECIES TAXONOMY}

Table 1 lists the total numbers of species names found in the IODP radiolarian TNL that are attributed to the more prolific radiolarian taxonomic authors, sorted by number of published names. Authors publishing in the first century are listed first, with authors grouped into early German workers, other early workers, and selected later workers. Species names are attributed to these workers if the author field in the TNL begins with the author name, and are counted as valid if the name has been used in deep-sea drilling research either as originally published, or if the name is used as a valid species but in a different combination, e.g. regardless of current generic assignment. The majority of remaining names with evaluation information are subjective synonyms of various sorts, although some names are variant forms, or are classified in the list as 'unknown', or have other status, so the total evaluated names per author is usually a little higher than the sum of the valid and synonym values. Table 1 also lists the number of names found in the TNL which have no evaluation information at all. These are names added to the TNL by compilations from the primary taxonomic literature but which have never been used in over 40 years of deep-sea drilling research, or in the Recent plankton research literature. Authors who published only, or primarily on Palaeozoic or early Mesozoic material, and whose names would thus not be expected to be found in deep-sea drilling reports, are marked with an asterisk. Such authors' taxonomy cannot be evaluated using the TNL, and will not be discussed to the same degree as authors whose work was primarily on Cenozoic-Recent material.

As expected, Haeckel is by far the dominant author of new species names, although Rüst and Ehrenberg also published nearly a thousand species each. Several other early authors published 200 or more names, including Vinassa de Regny, Hinde, Squinabol and Tan Sin Hok. To place this in context, Campbell and Clark (usually publishing together) are among the few active (but very prolific) authors from the transition period between early and modern era work, and have c. 500 species in the TNL - by far the highest number for any author more recent than the first phase of research prior to $c$. 1930. Some authors from the modern era (1960 plus) also have high total publication numbers (100 to 200 species), including Foreman, Riedel \& Sanfilippo, 
Early radiolarian taxonomists: species of German workers

Table 1. Summary of records for radiolarian species names in the IODP TNL list (Lazarus et al., in prep.)

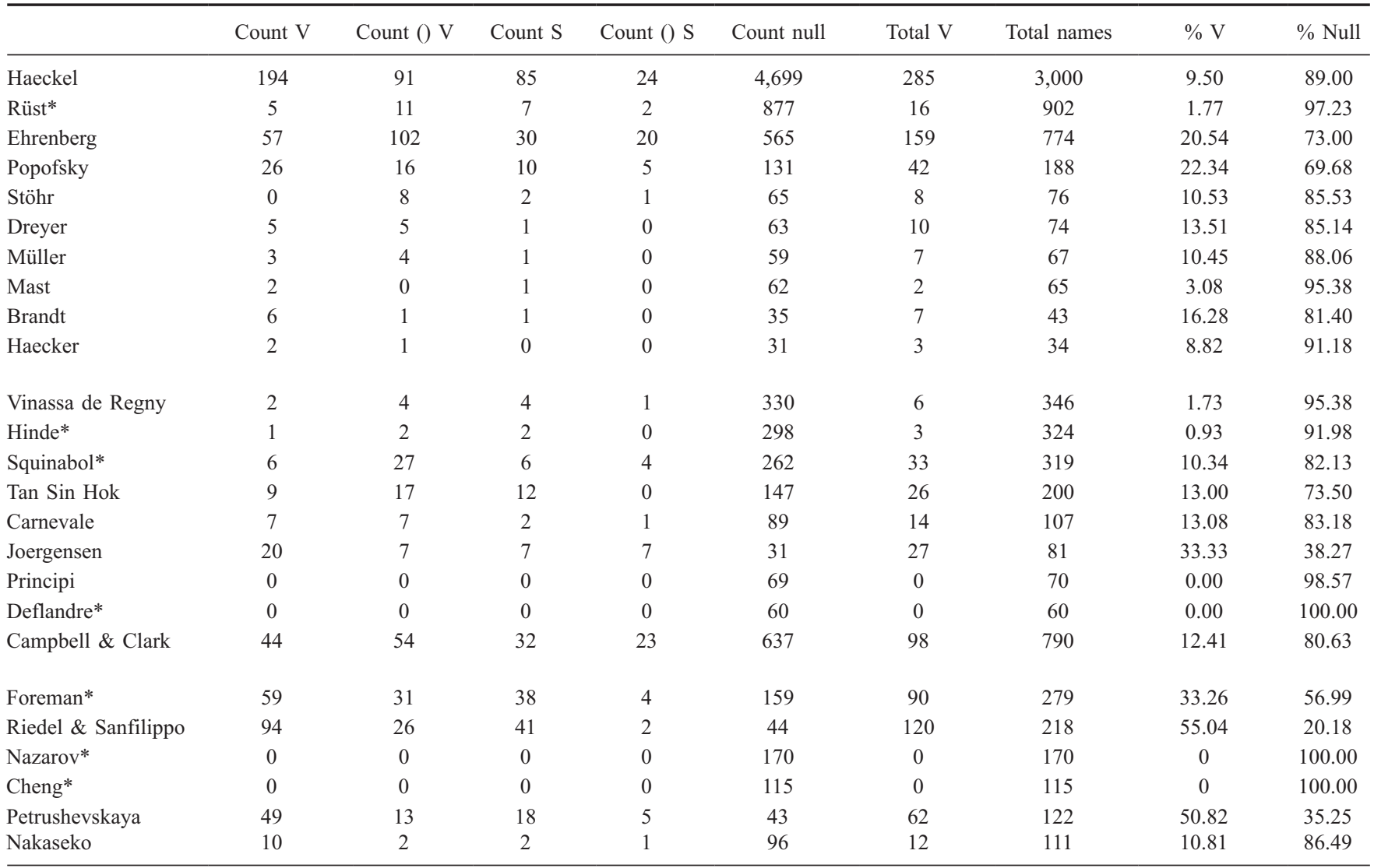

Counts for the non-German authors are based on all names matching simple search strings and thus include 10-20\% name variants (spelling errors, embedded qualifiers such as '?', subgeneric names etc). True ' $\% \mathrm{~V}($ alid)' values thus are probably also $10-20 \%$ relatively greater than given here. Haeckel values are approximations (see text).

*Authors who published primarily on pre-Cenozoic materials: the extent to which their names are still used cannot be estimated from the IODP TNL which is dominantly Cenozoic usage.

Nazarov, Cheng and Petrushevskaya, but none approach the numbers of new species introduced by the most prolific early authors (Haeckel, Ehrenberg, Rüst, Hinde, Squinabol, Vinassa de Regny), all of whom have species counts $>300$.

Among the early authors, although many nationalities are present, a dominance of German workers is apparent: even were Haeckel's contribution to be no larger than that of the most prolific non-German worker (Vinassa de Regny), German specialists contributed at least $50 \%$ more names than all other early workers combined. This justifies, at least in part, restricting the remainder of the paper to German authors, as they have contributed the majority of the legacy of species names, particularly for Cenozoic and living taxa.

\section{BIOGRAPHICAL SKETCHES AND SUMMARIES OF THE TAXONOMIC WORK OF INDIVIDUAL EARLY GERMAN WORKERS}

\section{G. Ehrenberg (1795-1876)}

Other than a single brief and taxonomically irrelevant reference to radiolarians by Meyen (1834), the oldest, and the oldest substantial study of radiolarians began with Christian Gottfried Ehrenberg, who described a half-dozen species of both Spumellaria and Nassellaria in 1839 (Ehrenberg, 1839), and who followed this with c. two dozen additional papers, at least partially on radiolarians, for nearly 40 years afterwards. A detailed listing of these is given in Suzuki (2009), and the correct publication dates in Lazarus \& Suzuki (2009).

C. G. Ehrenberg (Fig. 2) was born in the small German town of Delitzsch, the son of a judge (biography summarized from Moltrecht, 1995; Baker, 1997; Jahn, 1998). Following his parents' wishes he originally studied theology, but switched after a couple years to medicine and natural sciences. His doctoral thesis on fungi in the region around Berlin was well received and he soon came into contact with the - by then - famous older explorer and scientist Alexander von Humboldt, who had eventually settled in Berlin as the honoured guest of the Prussian king. This contact gave him and his close friend and fellow University of Berlin faculty member Wilhelm Hemprich the chance to join an archaeological expedition to the Near East, under the leadership of the Prussian general von Minutoli. Ehrenberg and Hemprich collected many thousands of biological and geological specimens of all sorts, and shipped these back to Berlin over the several years of the expedition. The endeavour, however, eventually ended in disaster, as funds for the expedition ran out, and the majority of the members died of disease in the Near East, including Hemprich. Further disappointment awaited Ehrenberg on his return to Berlin, where he discovered that a large part of the materials he had shipped, and whose study he expected 

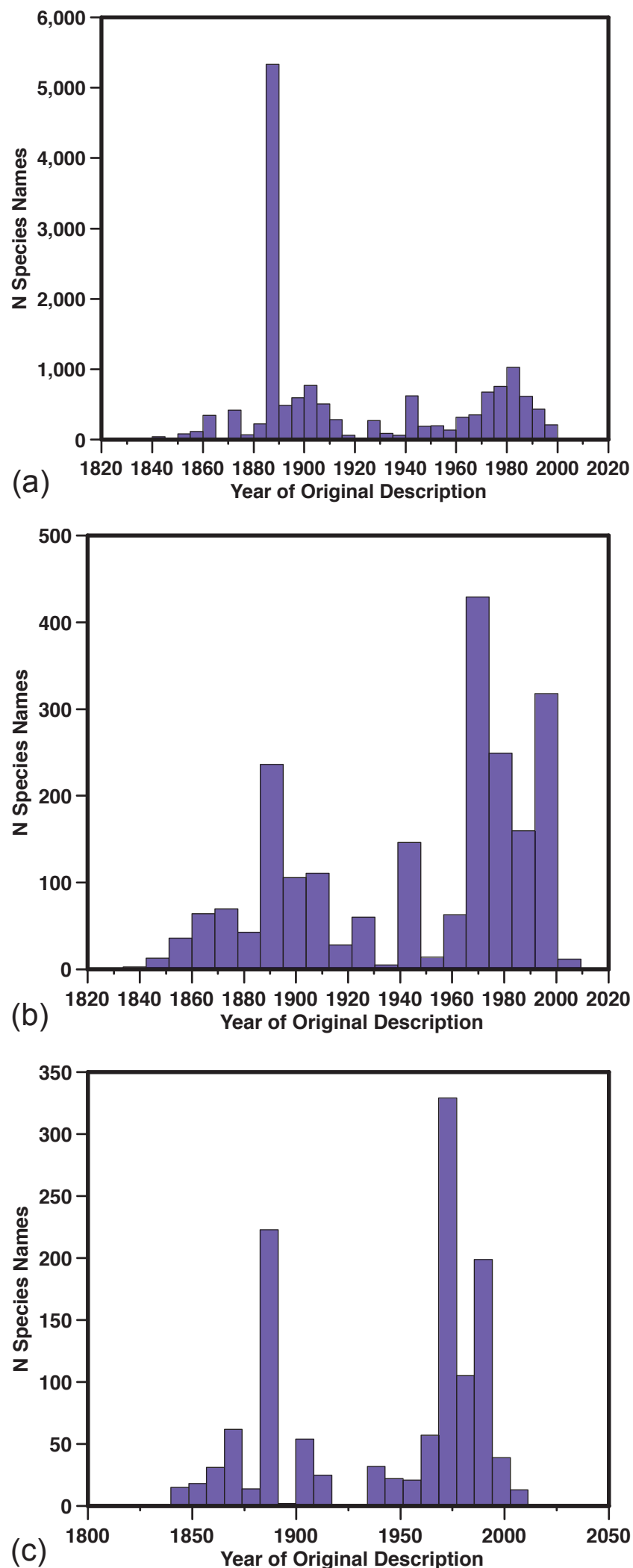

Fig. 1. Radiolarian species names published by calendar year, extracted from the IODP TNL database: (a) all species; (b) species that occur in deep-sea drilling literature; (c) valid species in deep-sea drilling literature. 


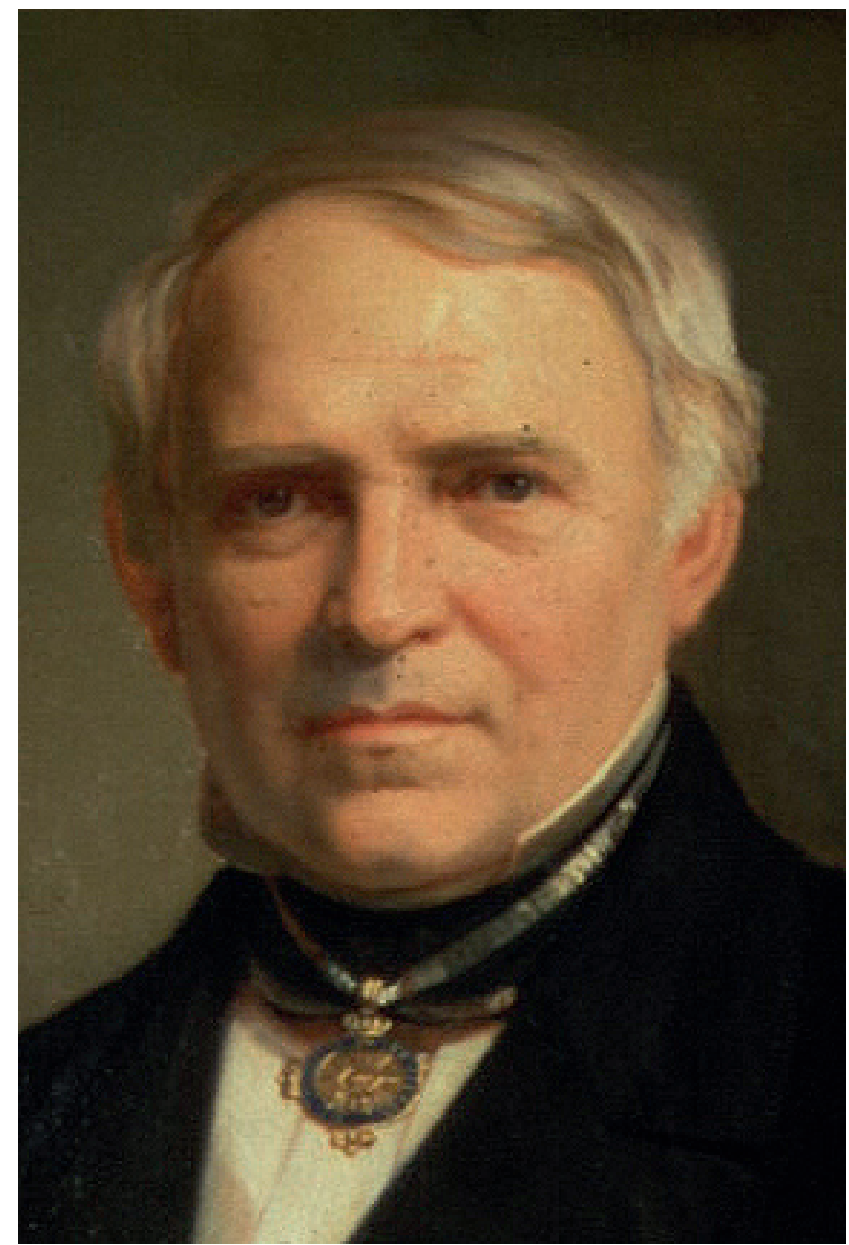

Fig. 2. Christian Gottfried Ehrenberg. Source: Museum für Naturkunde, Berlin.

would form the foundation of his career, had already been given to other scientists for study. Ehrenberg turned his attention soon afterwards to a field that still remained untouched by others - the study of microscopic organisms, which was just becoming feasible with the spread of better quality microscopes in the early nineteenth century. After one other (much better financed) expedition to Russia, Ehrenberg largely ceased travelling and concentrated on his studies in Berlin. Ehrenberg's scientific theories (see below) were soon eclipsed by later work and thus he has been rather neglected by historians of science.

Ehrenberg's microscopic researches covered virtually all possible organisms that could be resolved by the microscopes of his day, and that would fit on the microscope stage. He did not significantly examine bacteria, and the largest objects were fragments of invertebrates a few millimetres long. However, within this size range virtually every type of organism was observed and described, many for the first time. In addition to protists he described small multicellular forms, such as tardigrades, but the large bulk of his preparations and species descriptions are of protists and, in particular, of diatoms. Radiolarians were a significant but definitely secondary subject of study for him. Ehrenberg, as the first scientist to systematically study and prolifically publish on microorganisms, soon became famous among scientists and laypersons alike for his work, and people would routinely send him material for examination. Although an avid collector himself, the activities of this extensive public meant that most of the material he studied came from elsewhere. In particular most of the radiolarian material came from land sections of Cenozoic age that were sent to him this way in the mail, or which were given to him by others who had done the collecting work. Many of his early radiolarian species descriptions come from Neogene biosiliceous sediments from Italy, or from the Palaeogene biosiliceous sediments of Barbados (e.g. the Oceanic Formation). Later, he supplemented this with deep-sea marine sediment samples, although the technology for recovering material from the deep ocean was at that time in its infancy. Ehrenberg, however, studied very little in the way of marine plankton - the first major scientific ocean expeditions were still in the future, and he did not take part in pioneering local plankton studies, such as those carried out by the next generation of scientists like Haeckel. He thus had no knowledge of the biology of the living radiolarian cell and ignored published work by others (Haeckel, 1887). Ehrenberg, of course, extensively studied living cells of numerous other protists, as well as of multicellular organisms, and was the first to frame general hypotheses on protistan biology.

Ehrenberg's ideas on protist biology were unfortunately largely wrong. He believed that the various organelles visible to him in the microscope were not just analogous, but actually homologous to the organs of larger, multicellular organisms. During the early years of study this was understandable - the idea that cells were basic to all life forms was published only initially in 1839 (Schwann, 1839). However, cellular theory developed rapidly and to most scientists of his day it was soon clear that protists (or Infusoria, as Ehrenberg called them) were not simply small versions of larger animals, and Ehrenberg's stubborn refusal to change his views substantially diminished his reputation (Jahn, 1998). The unicellular nature of protists was first determined by von Siebold in 1845 (Scamardella, 1999). Ehrenberg was also unconvinced by Darwin's new evolutionary theory, putting him on the wrong side of yet another major debate. Ironically, considering how valuable fossil protists are to biostratigraphy, Ehrenberg's basis for rejecting evolution rested in part on his opinion that there was no significant change over time in his fossil samples (Clara Ehrenberg, 1905, pp. 147-148). Lastly, Ehrenberg spent a great deal of effort in tabulating the distribution of his 'Infusoria' species (mostly freshwater materials) in various samples and environments, in an attempt to determine the factors controlling the distribution of forms. This work, which occupies a substantial part of almost all of his publications, established some basic limits to distribution both biologically, and geologically (e.g. that microfossils are not found in volcanic rocks, dolomites, etc.), but did not yield much detailed insight. In part this may be explained by the limited environmental and geological information available at the time, which was probably mostly insufficient to indicate local causal controlling factors (e.g. subtle differences in $\mathrm{pH}$, currents, nutrient concentrations and water column stratification; accurate, precise geological ages); and in part the very broad, often intercontinental geographical distribution of morphospecies in many protists, whose uniformity is only today beginning to be questioned as molecular studies of species structure become more widespread.

As was typical for early taxonomic work, descriptions were rather brief, and the illustrations often not much more than sketches, 
which has meant that the meaning of many of Ehrenberg's names are unclear. This is particularly true for small protists, such as diatoms, but affects also Ehrenberg's radiolarian species to some extent. Ehrenberg's particular strength was his objective observation of morphology, and his meticulous, consistent methods of documenting his observations. Ehrenberg worked before the concept of type specimens for species had become established, and there was little in the way of standards for publication of new taxa names either. Yet he not only documented most of his species with published figures (even if often only many years after first introducing the new name in the literature), he also carefully preserved the original material and microscope preparations for future generations of scientists to study (Lazarus, 1998; Lazarus \& Jahn, 1998). In this he was helped by his daughter Clara, who for much of her adult life served as Ehrenberg's assistant. Clara was also responsible for labelling, organizing and cataloguing Ehrenberg's collections, which after his death were deposited with the university (1876), and transferred to the Museum für Naturkunde (MfN) in Berlin when this institution was opened in 1889. The Ehrenberg collection, however, was not much used at first, possibly as revisions were not yet seen as necessary, and later (e.g. from 1920 on) a variety of problems made access difficult, including two world wars, financial crises and the Cold War, which separated the MfN in east Berlin from the large majority of protozoologists, diatomists and micropalaeontologists who worked in western countries. Restoration work on the collection began gradually 20 years ago with the reunification of Berlin, and the major re-documentation of Ehrenberg's radiolarians was achieved only recently (the 5 Ehrenberg radiolarian papers in Tanimura \& Aita, 2009: Lazarus \& Suzuki; Suzuki; Suzuki et al. $a$, b; Ogane et al.). In this volume, Suzuki (2009) notes that Ehrenberg published a total of 532 species names, although 31 of these are considered to be nomen nudum. Excluding all obvious variant names from the TNL gives a very similar, if slightly higher value of 547 species. Around $20 \%$ of these species names are considered to be valid today, either as published or in new combination. This percentage will most likely increase in the future as workers make use of the re-illustrated type series materials in Tanimura \& Aita (2009) to typify and establish priority for many Ehrenberg species names whose use until now was uncertain. Ehrenberg also published higher-level taxonomic names, including genera (as was required by Linnaean nomenclature) and higher rank taxa. He is the author of 72-82 genera himself (the former according to Suzuki, 2009, the latter according to the Radworld database) and, from designation by later authors (particularly Haeckel), no less than 134 radiolarian genera have Ehrenberg type species (Suzuki, 2009). The majority of Ehrenberg's own generic names are still in use today, although given the unstable state of higher-level taxonomy in radiolaria it is unclear how many of these are actually valid (distinctive monophyletic clusters of species).

Ehrenberg's higher rank taxa were very limited in number and used to define only larger divisions between different groups of protists. A total of 38 records above the genus level are found at WoRMS, scattered among many different high-level protist groups, including several families of foraminifera. Ehrenberg introduced, according to Haeckel (1862), a total of 8 approximately family-level taxa for the polycystine radiolarians, including Spumellaria, a few other family names, and Polycystinea itself. As the term that now defines microfossil radiolarians, the definition of Polycystinea is worth noting explicitly. Ehrenberg introduced this rather briefly, in a single (but typically very long) sentence in the 'Abhandlungen' of 1838 (printed and published 1839). It followed a comment that glassy, acid-insoluble forms were found in the Neogene material from Italy that he was examining that were otherwise similar to foraminifera:

As the organic [häutige] or calcareous substance of the shell is dominant in the large majority of foraminifera [Polythamien], and the organic [häutige] or siliceous substance of the shell is equally dominant in the diatoms [Infusiorien], so that until now no calcareous-shelled diatom or siliceous-shelled foraminiferan has been seen, I have decided to assign these siliceous-shelled forms, until more is known of their biology, to the foraminiferal [Infusiorien]-like protists, near the armoured Amoeboa or [Kapselthierchen], Arcellina, as a specific, limb forming [Glieder bildende], ?[corallenstockartige Formenreihe], in their own family, with the name Arcellina composita or Polycystina, little cell animals [Zellenthierchen]. (Ehrenberg, 1839, p. 117 - brackets and '?' used where the meaning is uncertain).

The citation in a footnote on this page by Ehrenberg to an earlier similar statement in his 1838 Infusorien book does not reveal an earlier use of the name Polycystina, either in the text or the 'Register' (index) to his volume. His citation appears to refer to the use of 'Zellenthierchen', which in the Infusionsthierchen appear on p. 154 and plate 11, and are some form of algae, clearly unrelated to radiolarians. Such confusing cross-links between different forms under the same taxonomic name are due to the often (v. modern) radically different taxonomic concepts used by early workers as they first attempted to structure their observations.

\section{J. Müller (1801-1858)}

A contemporary of Ehrenberg, Johannes Müller (Fig. 3) was one of the most famous German biologists of his generation, who contributed to studies of physiology/medicine, general biology and made early studies of the biology of many marine groups. Starting from humble beginnings, his intellectual abilities were recognized and, after completing his studies in Berlin, he became professor first in Bonn and then, following his former professor, from 1833-1858 in Berlin. He taught many students, among them Haeckel. He began to study radiolarians only shortly before his premature death (from illness or suicide is unclear) in $1858 \mathrm{He}$ published only three substantial papers on radiolarians (Müller, $1855,1856,1859)$ with his last, and most substantial, radiolarian paper being published posthumously. Müller began the study of radiolarian biology, using methods in part pioneered by him in the study of other marine groups. He described a total of 69 species, including both polycystines and acantharians (establishing for the latter the geometric rule by which the primary spicules are arranged). Müller's importance to radiolarian studies lies primarily in his initiation of a more biological approach to their study, his training and inspiring of later researchers, particularly Haeckel and, to some extent, due to his high reputation, simply by choosing them as a study subject, lending radiolarian research a degree of importance. The location of Müller's studied materials, if any were deposited by him, is unknown. They are not within the micropalaeontology collections of the Museum für Naturkunde, which holds the materials collected by Ehrenberg, another Berlin 


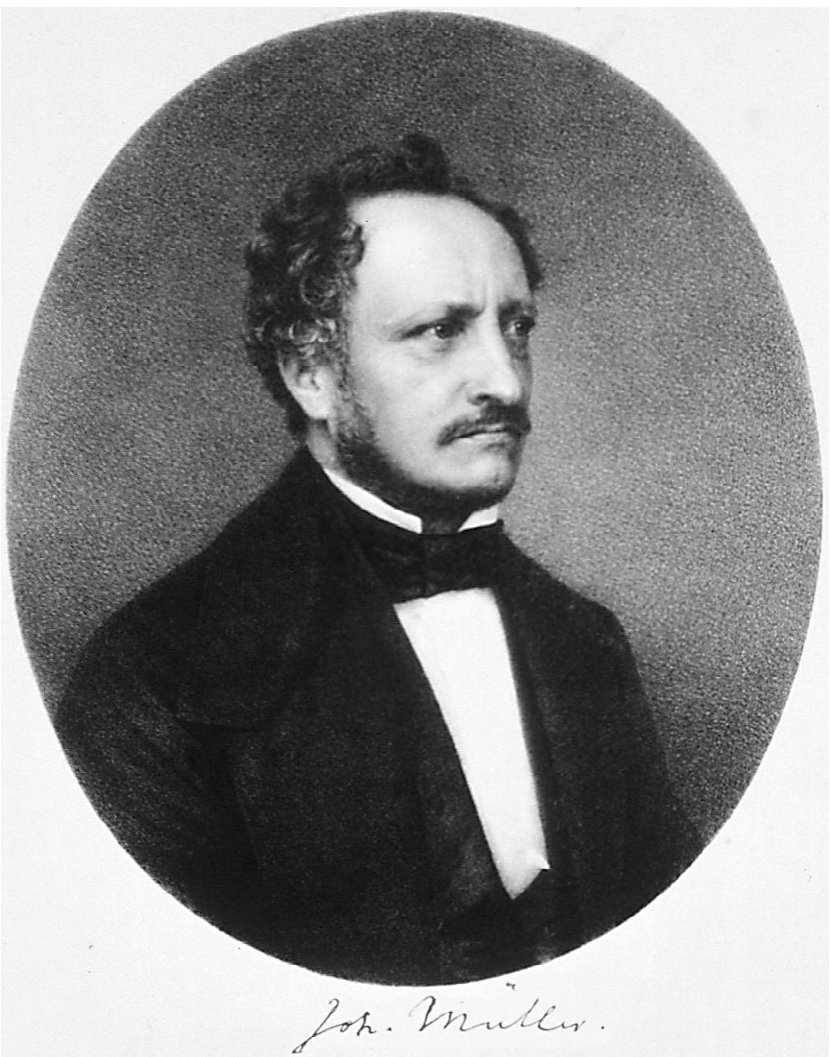

Fig. 3. Johannes Müller. Source: Humboldt Universität, Berlin.

professor, but might possibly still exist in one or other of the Museum's, or university's biological collections.

\section{E. Haeckel (1834-1919)}

Haeckel's life and radiolarian studies. Ernst Haeckel (Fig. 4), born in Potsdam and, like Ehrenberg, the son of a judge, grew up in the small central German town of Merseburg (coincidentally, only c. $30 \mathrm{~km}$ away from Ehrenberg's home town of Delitzsch). Following his father's wishes he studied medicine initially, but soon after completing his exams took the opportunity to travel to Italy and study what had long interested him more - nature. After some months at the Italian coast and with little success in studying marine life (much time was also spent touring with friends and other diversions), and with time beginning to grow short, Haeckel decided to focus on the group last studied by the eminent J. Müller shortly before his death: radiolaria. Haeckel had brought a copy of Müller's paper with him and, with a wealth of material available off Messina, Haeckel began the first of his major studies of nature. This study became Haeckel's Habilitations thesis (published, in Latin, in 1861 - a degree which in the German academic tradition is required to apply for a professorship) and, in 1862 part of his first major monograph, (nearly 600 pages in all) describing, according to a listing of species in the volume index, 144 new species of radiolarians (of which 48 polycystine species are included in the TNL). Haeckel's (1862) monograph included polycystines, phaeodarians and acantharians; the distinctive mineralogy of the latter he recognized, although he did not identify that it was celestite. This monograph is extremely important as publishing for the first time a detailed survey of both skeletal and protoplasm structures.

Haeckel had previously skimmed a German translation of Darwin's 'Origin of Species', but only when re-reading it in November 1861 did he become convinced of the correctness of Darwin's theory. From this point on, however, he became an enthusiastic supporter, and he decided to try to include a 'natural' classification of the radiolarians in his new monograph. This is clear from the introductory section of his work, where he says:

Grade dieser überraschend grosse und unerschöpfliche, ja fast verwirrende Reichthum an den seltsamsten und höchst phantastisch ausgeschmückten Gestalten, wie man sie sonst im Thierreiche nicht zu sehen ge- wohnt ist, macht es höchst wünschenswerth, in der bunten Masse des verschiedenartigsten Details gewisse Centralpunkte zu fixiren, um welche sich die näher unter einander verwandten Gestalten ver- sammeln und natürlich gruppiren lassen, und es erscheint dies doppelt nothwendig beim Versuche einer systematischen Disposition, da das Skelet, beim Mangel fast aller charakteristischen Anhaltspunkte in der Structur des Weichkörpers, in seiner scharf und bestimmt ausgeprägten Form allein die Mittel liefert, die Arten und Gattungen zu unterscheiden und in natürliche Familien zu sammeln. Auch, werden wir bei diesem Versuche selbst sehen, dass trotz der unvergleichlich mannichfaltigen Ausbildung der Skeletform nach den verschiedensten Richtungen hin, dennoch ein gemeinsames Band durch die ganze Reihe sich hindurch zieht, und selbst die scheinbar am weitesten entfernten Formen durch vermittelnde Uebergangsstufen verbindet. So werden wir auch unten bei dem Versuche eines natürlichen Systems der Radiolarien wahrnehmen, dass sich einige wenige Grundformen, ja vielleicht mit ziemlicher Sicherheit ein einziger fundamentaler Typus auffinden lässt, aus dem die ganze reiche Kette durch fortgesetzte Abzweigung divergirender Glieder sich entwickelt. Wir werden am leichtesten diesen Ueberblick gewinnen, wenn wir zunächst die einfachsten, nur aus wenigen zer-streuten oder verbundenen Kieselstücken bestehenden Skelete in's Auge fassen, und dann allmählich durch die einfacheren, hauptsächlich nur aus verbundenen Stachelradien bestehenden Mittelformen zu den ebenso complicirt in Kammern abgetheilten, als zierlich architektonisch ausgeschmückten Gitter- gehäusen der sogenannten Polycystinen emporsteigen (Haeckel, 1862, p. 37).

Precisely this surprisingly large and inexhaustible, indeed almost confusing richness of strange and highly fantastically decorated forms, which otherwise in the animal world are not seen or are uncommon, makes it highly desirable, to fix in the diverse volume of various details some anchor points, around which closely related forms collect and allow themselves to be naturally grouped, and it seems doubly necessary when attempting a systematic assignment, that the skeleton, due to the lack of almost all characteristic reference points in the structure of the protoplasm, in its clear and specifically expressed forms, alone provides the way to 


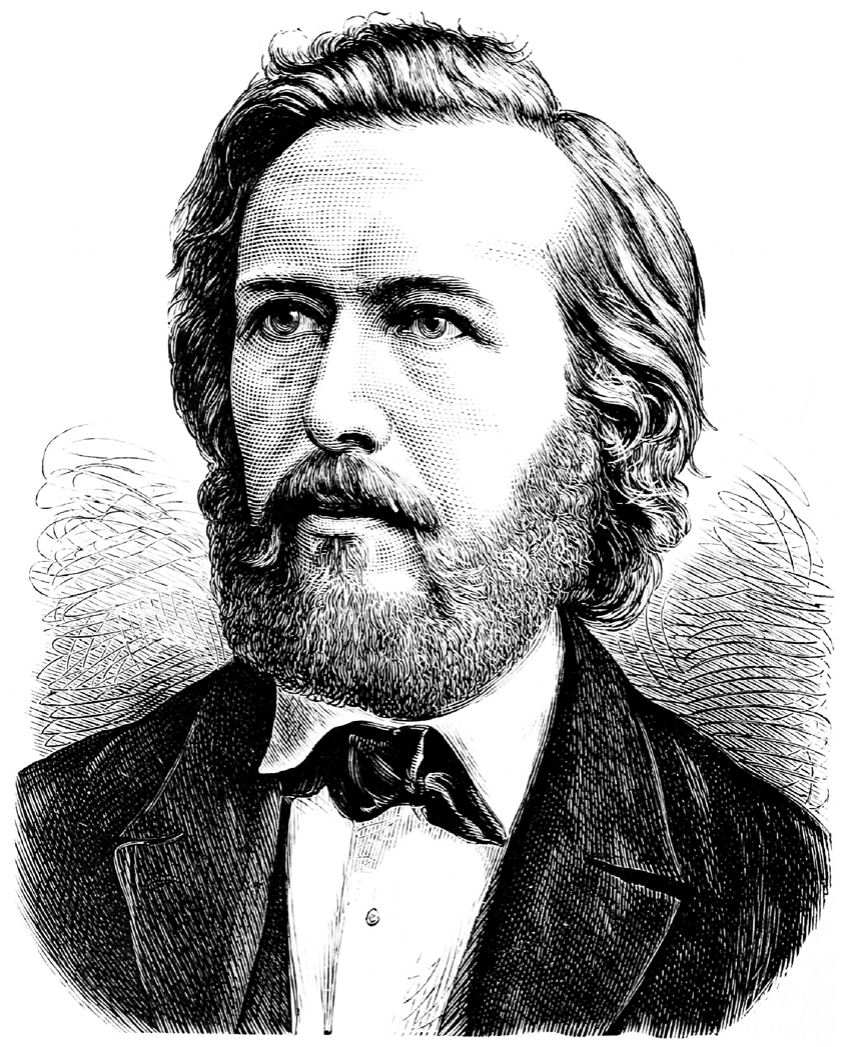

Fig. 4. Ernst Haeckel.

distinguish species and genera and to collect these into natural families. Also, we see by this attempt that, despite the incomparably diverse development of the skeletal form into the most different directions, none the less a common thread runs through the entire series, and even the apparently most discrepant forms are connected by intermediate transitional stages. So we will also notice in attempting [to define a] natural system of radiolarians, that a very few basic forms, indeed almost certainly a single fundamental type can be discovered, from which the entire rich chain [of forms] through continued branching of divergent forms develop. We can most easily obtain an overview, when we first look at the simplest skeletons, comprised only from a few scattered or bundled silica elements, and then gradually through the simpler middle forms, primarily made of radially bundled spines, then move up to the complex, in chambers divided, decorated meshwork shells of the thus named Polycystines (translation by the author, deliberately keeping as much as possible of the original language's structure and style).

The key points of the above text are: the desire to define natural groupings; the admission that only skeletal morphology is useful for this; and the belief that this higher classification revealed fundamental forms, from which the entire range of morphologies could be derived by branching chains of morphologic relatedness. It should, however, also be noted that Haeckel had most likely already completed a large part of his observations and analysis of his material by November 1861, so that the extent to which he re-did his taxonomy to support his goal of creating a natural classification is, without more detailed examination of his drafts and unpublished writings, unclear.

In his 1862 monograph, Haeckel created a fairly modest higher level (e.g. supra-generic) classification consisting of 15 families, many with subfamily ('tribe') levels, for a total of 32 higher taxa. This number is only somewhat higher than those defined by Ehrenberg, considering that several of Haeckel's families referred to Acantharia and Phaeodaria, groups not studied by Ehrenberg. This monographic study of radiolarians established Haeckel as a young scientist of importance. He transferred his research focus soon afterwards to other groups of organisms, and the more general aspects of evolution and development for which he is best known. He returned to extensive radiolarian research only many years later, when he was offered the opportunity to study the extensive collections of living and fossil radiolarians collected during the Challenger Expedition.

Challenger work. The Challenger Expedition of 1872-1876 was perhaps the most famous of all oceanographical expeditions, and was the first that was dedicated to basic scientific exploration. Haeckel, along with many other scientists, was asked by the managers of the Challenger Expedition soon after the ship's return to examine and report on the expedition's collections, specifically for radiolarians, dictyoceratid sponges and jellyfish. He began his radiolarian work in 1876 and delivered the report in increments to the Challenger office between 1884 and early 1887 (Murray, editorial preface, in Haeckel, 1887). Extracts of the work in progress were published separately, e.g. Haeckel (1881) but were provisional in nature to the final volume. This final published report (1887, number 40 in the Zoology series of 83 reports) was not only the largest report of the entire series, it was, and probably still is, the largest single volume on radiolarians ever published, and may be one of the largest single-author works ever published on protists as well. It consists of an introduction (188 pages), four taxonomic sections (Spumellaria, Acantharia, Nassellaria and Phaeodaria, 1803 pages), and a separate volume of plates (360 pages for 140 plates). According to Aita et al. (2009) the report covers a total of 739 genera and 4318 species; with the majority of the species, and many of the genera being new. Haeckel's (1887) report also summarized and subsumed all prior work on radiolarians up to that point, including, for example, many of Ehrenberg's species and genera, and not infrequently also used species from earlier works as the types for new genera of Haeckel's. This volume increased enormously the number of species described in the literature and became the main reference and orientation for radiolarian taxonomy for many decades to come. Just how many new fossilizable polycystine species Haeckel published is harder to determine as all general citations lump fossilizing polycystines with non-fossilizing groups, such as belloids, collozoids, acantharians and phaeodarians. The estimate used in this paper of $c .3000$ is based on counts of 'n. sp.' in the Challenger report text sections on fossilizable spumellarians and nassellarians, plus counts of similar groups in the 1862 monograph.

An individual evaluation of Haeckel's species and genera from this work is obviously beyond the scope of this paper. It is, however, significant that many of the species described by Haeckel have been difficult for subsequent workers to confirm or use. At least one recent specialist once commented (and the present author would agree) that only about one-third of Haeckel's illustrations 
are identifiable in comparable material today, another third had not been seen but, based on the description and illustration, might well exist, and a last third seemed to be so unusual in form that one could suspect them of being, if not invented, at least misinterpretations or chimeras, created by attempting to illustrate complete specimens from a set of broken shells that were not conspecific. This judgement will be returned to in the statistical evaluation of older radiolarian species names that is given below.

Haeckel (1887) also introduced a much enlarged and substantially more complex higher-level taxonomy for the radiolaria. Whereas in his 1862 monograph he proposed only $c$. two taxonomic ranks beyond the genus (family and subfamily, plus a rather minimally developed clustering of families into singlecelled v. colonial), he now used at least five: Subfamily, Family, Order, Sublegion and Legion, plus unnamed intermediate-level categories equivalent to sub-orders and the like. In 1862 he had only 15 families and 17 subfamilies, in 1887 he now proposed 20 orders and no less than 85 families, although some of the earlier subfamilies had effectively migrated to family, and earlier families to order rank, plus an uncounted number of subfamilies. This massive increase in higher-level taxa reflected partially, of course, the much greater range of material he was studying, which now included a global collection of living material plus substantial numbers of fossil forms. However, at the level of families, it must be assumed that many, probably most, were also present in the Mediterranean material he had used for his 1862 monograph, so the majority of this expansion reflects a change in thinking about higher-level classification. An indication of how this supra-generic taxonomy reflected Haeckel's thoughts can be seen in (new to the 1887 volume) a named 'Biogenetic' section with explicit named subsections for ontogeny and phylogeny - concepts, or at least terms, which he had himself created from his broader biological research over the last 20 years. The phylogenetic section contains trees - a new form of classification diagram, with the various families, orders etc. used as labels for several evolutionary trees, with the rank of the taxa labelling and indicating the various clades and enclosed subclades (Haeckel, 1887, p. cvii, etc.). Much more so than in 1862, higher-level classification had become linked with evolutionary hypotheses. In the text for this section Haeckel continues the style of phylogenetic hypothesizing that was present in simpler form in his 1862 monograph, suggesting a series of morphologic transitions between higher taxa based on similarities in characters in specific subcategories in each that might serve to link the higher taxa together. As Haeckel noted himself (e.g. cxviii, for Nassellaria) it is often possible to create many different hypotheses of transformation between series of forms, so that a preferred solution is not apparent. It is only with the development of cladistics nearly a century later that more rigorous (though not always any less ambiguous) approaches to phylogeny reconstruction using only morphological characters became possible. Haeckel, of course, also championed the use of ontogenetic information, but since this was largely still missing in 1887 (and is still missing today), his ontogenetic section is fairly brief and is based largely on comparative morphological arguments, mixed together with a fair amount of speculation about 'stages' of development based, it seems, on his own ideas about recapitulation. Although radiolarians have an excellent fossil record, which has been used for many studies of phylogeny (e.g. lineages of ancestor-descendant species, Sanfilippo et al., 1985), in Haeckel's day it was still much too incomplete to be of much use, particularly for the phylogeny of higher taxa, as he noted in his section on 'Geological Distribution'.

Haeckel noted that his classification, although it strove to be 'natural', i.e. to reflect the evolutionary phylogeny, was still not perfect and had some artificial aspects. In fact, there was little basis for many of his higher-level taxonomic categories. Many other radiolarian workers have commented on the deleterious impact Haeckel's artificial classification had on the development of radiolarian stratigraphy, in that the artificial categories not infrequently lumped very old forms (Mesozoic or even Palaeozoic) with quite recent ones in the same genus, giving the impression that radiolarians were not useful for biostratigraphic work (e.g. Riedel, 1967; Kling, 1978). It is also important in that incorrect choice of characters for higher-level taxa definitions will create artificial dichotomies (or polytomies) in the structure of lower-level entities. For example, the number of segments in 'cyrtoid' nassellarians was chosen as a top-level character for determining families (one, two, three, many), together with the number of radial elements (feet, ribs etc. - none, up to three, four or more). This resulted in two genera - Pterocanium and Tripocyrtis - which both have three thoracic ribs prolonged into three terminal feet, which are latticed at the base; and two more - Theopodium and Dictyophimus - for the same forms but with solid feet structure. Pterocanium and Theopodium have three segments while Tripocyrtis and Dictyophimus have two. Unfortunately, while the number of segments in a nassellarian shell is today still an important diagnostic character, it is also understood that there is variability, and that the last 'segment' morphology needs to be determined more precisely, as in some cases it may be considered to be a true segment, in other cases only a secondary, less regular growth which is not homologous. Similar variation in character expression is also thought to exist in the presence or absence of lattice structure in the terminal feet. Thus, within a group of closely related forms (e.g. a single genus, or even a single species) specimens may exist that show the various combinations of character states that define these four genera. Haeckel defined 21 species in Pterocanium, 2 in Theopodium, 4 in Tripocyrtis, and 22 in Dictyophimus, many of which appear in practice to be largely redundant duplications of species in one of the other three genera. Equally problematic is the failure to use characters which today we would consider to be reliable generic or family-level markers. Some of the species in these three genera listed in Haeckel (1887) would today be placed in distinctly different modern families (e.g. Plagiacanthidae v. Theoperidae). In all, Haeckel introduced 1275 generic names (plus numerous subgeneric names), nearly an order of magnitude more than any other author in the history of radiolarian research (Radworld gives the next highest as Kozur and Möstler with 159 genera, followed by Ehrenberg with 82). This is approximately half of all generic names in the Radworld database (2552), and the large majority of the other generic names refer to Mesozoic and Palaeozoic material not studied by Haeckel.

Haeckel was certainly not alone in his attempts to construct elaborate higher classifications, and to hypothesize evolutionary links between forms. Haeckel, though, seems - at least within the scope of this current study - to have been the initiator, and thus have provided an unfortunate methodological framework for much future research by other authors who emulated this taxonomic style. 
Haeckel's studied materials. In contrast to Ehrenberg, Haeckel did not invest much time or effort in permanently documenting and arranging his materials for future archiving (Lazarus, 2000). In his early studies from Messina he kept detailed notes, drawings and micro-slides of the material he was examining. This material is still preserved in part in his former home (now the Ernst Haeckel Haus Museum in Jena), although the slides partly do not have clear labels (Sakai et al., 2009). The slides used for his later, and more extensive work, summarized in the Challenger report of 1887, have apparently been lost (Lazarus, 2000; Aita et al., 2009). This consisted of slides and original samples not only from the Challenger Expedition but also plankton material collected by other ships, such as the Raabe (collector) material from the Indian Ocean. There is an indication in Haeckel's unpublished notes that he had, late in life, sent the bulk of his slides to someone in Berlin for further examination, but the recipient and subsequent fate of this material is unknown (E. Krauße, former curator, E. Haeckel Haus, Jena, pers. comm. 1998). A few slides were also apparently simply given away by Haeckel to relatives, and one of these small collections has survived in private ownership (the Benn collection, Aita et al., 2009). Fortunately, Haeckel made many duplicate slides of the more important samples in his studied materials for use in commercial 'teaching' sets, and several of these sets have survived in Jena, London and Berlin (Lazarus, 2000; Aita et al., 2009). Further, the original Challenger plankton and sediment samples have been carefully curated by the Natural History Museum in London, and are also available for study (Lazarus, 2000; Aita et al., 2009). These materials are important in that Haeckel, like Ehrenberg, did not designate type specimens, or explicitly label any of his materials as types. The papers of Aita et al. (2009) and Sakai et al. (2009) have begun the process of re-documenting Haeckel's material, although so far this work has been restricted to a subset of the species he described from plankton material.

Haeckel as a scientist and historical figure. Of all scientists who have devoted a large part of their career to the study of radiolaria, Haeckel is, even today, certainly the most famous, and his name is also the one most commonly associated with radiolarian research by other scientists and the general public. Haeckel certainly made a great contribution to radiolarian research in that his radiolarian illustrations were so popular that the general public finds in them, even now, a source of wonder, providing a degree of popular support for radiolarian studies that most groups of protists lack. Haeckel's fame rests, however, primarily on his general contributions to the study, and most particularly to his promotion of Darwinian evolutionary theory. In a number of popular books, along with numerous lectures, short articles and the like, Haeckel was an extremely influential popularizer of Darwin's theory of evolution. His books Natürlichen Schöpfungsgeschichte [Natural History of Creation] (1868) and Welträthsel [The Riddle of the Universe] (1899) were among the most popular of popular science books of his times, and were translated into over a dozen languages. As a scientist, Haeckel published substantial works on several groups of organisms but particularly on radiolarians, sponges and jellyfish. His most influential scientific work, however, was on general aspects of evolution, most completely documented in his monograph Generalle Morphologie (1866). As one of the major figures in nineteenth century science and, in particular, a major figure in the early development of Darwinism, Haeckel has been a popular subject for science historians, and several major studies have been published. Two recent volumes with highly contrasting views of Haeckel include Gasman (2004) and Richards (2008).

Haeckel is controversial in the history of both science and in history in general and, while most of this lies well beyond the scope of the current paper, it should be noted that Haeckel has been accused both of scientific fraud, and of being one of the intellectual progenitors of Nazism (Gasman, 2004; Richards, 2008). The eminent philosopher Karl Popper (1945, p. 66), for example, stated: "Hegel+Haeckel" is the formula of modern racialism'. These issues are relevant to his radiolarian work in so far that the style of working and thinking that led to these accusations is not unique to these specific works of his but are part of his basic personality and, as will be argued here, provide some clues to understanding his taxonomic work on radiolarians. As to the specifics of the accusations, briefly put (see e.g. Gasman, 2004 and Richards, 2008 for summaries):

- Haeckel was accused of using incorrectly labelled, partially duplicate figures to support claims of similarity between embryos of different species, as part of his documentation of how ontogeny relates to evolutionary history (his 'Biogenetic Law');

- Haeckel actively promoted the use of biological knowledge and evolutionary theory in broader human affairs (e.g. an oftquoted statement by Haeckel that 'politics is applied biology', Gasman, 2004) and specifically eugenics. He founded a philosophy ('Monism') which incorporated these beliefs and many members soon began to promote more radical versions of this, including racial purity. Several prominent members of his Monist society became active promoters of Nazism, and cited Haeckel and his philosophy in support of their views. Haeckel remained closely associated with these societies and neither denounced, or explicitly supported any of their views.

It remains unclear to what extent Haeckel should be judged guilty in either instance. It is possible to try to excuse Haeckel by arguing that the figures in his embryo scandal were innocently mixed up and that, at most, he was slow to correct the error (Richards, 2008). In the tragic application of his biological ideas to society, it has been argued that he was an abstract thinker with little responsibility for the specifics of a theory's use; that racism was widespread during this time; also, that the Nazi Party found Haeckel's works to include many things they did not like, and actually banned most of them (Richards, 2008). The fact that Haeckel never renounced the increasingly aggressive, racist statements of his Monist society members, however, is rather telling. In the many pages of discussion about Haeckel's role in these issues, his own personal characteristics and approach to science appear to be extremely important. There are two of these that seem to be particularly pertinent.

First, Haeckel appears to have been a 'romantic scientist' more in the tradition of Schelling, Humboldt and Goethe than many of his contemporaries, and certainly much more so than scientific practice today. This style of science stressed the integrative, 'big picture' understanding of nature and connecting scientific results to general philosophy (Richards, 2008). In contrast to a Popperian style that stresses falsifiability and minimalist style in drawing conclusions (including separating direct, e.g. scientific conclusions 
from more indirect, general societal ones), observations were for Haeckel a springboard to support his integrative theories and philosophy (Richards, 2008). The risk of this, as most scientists know even today, is to become so attached to an idea that one begins to overlook discrepant data, or even force the interpretation of observations to conform with the idea, instead of the other way around. It is a normal behaviour of which most have, at some point, been guilty. Haeckel, I suspect, was, because of his scientific style, however, particularly at risk of committing this sort of error. This same tradition also included an almost philosophical/ mathematical approach to morphology, looking to derive observed morphologies via idealized forms and transitions (Richards, 2008).

Second, Haeckel had, to a degree unusual for scientists, an emotional attachment to Darwinian evolutionary theory, which Richards (2008) explains as linked to Haeckel's personal life, beginning with his upbringing in the romantic view of religion, and later using evolution and nature as a replacement for more traditional religious faith that he rejected after the loss to illness in 1864 of his young wife. Haeckel, in writing his first monograph on radiolarians, was also still very young and to some degree may have had a desire to champion a new theory, particularly one his older professors looked down on (Richards, 2008). Whatever the reason, Haeckel had an intense desire for his scientific work to demonstrate the truth of Darwin's theory. This specifically is true of his first, and subsequent, works on radiolarians (Richards, 2008, pp. 68-75). This combination - emotional commitment to a theory, and an indulgent handling of facts - may have had an effect on his taxonomic work with radiolarians, as taxonomy can be used as one of the proofs of evolution (if not Darwinian mechanisms), particularly the hierarchical structure of taxonomic classification, with nested sets of similarities (e.g. homologies).

These aspects of Haeckel's work are not unique to his radiolarian studies. One particular example from Haeckel's other work illustrates how his scientific style and strong commitment to evolutionary theory interacted: his discovery, description and use, in many subsequent publications on evolution, of the microscopic plankton taxon 'Magnosphaeraplanula'. The following brief summary is based on a recent review paper by Reynolds \& Hülsmann (2008). Haeckel observed a microscopic, flagellated, ball-shaped organism in water samples he had collected in 1869 off Norway. He described this in 1870 as representing a new group of protists (the Catallecten - Haeckel had introduced the kingdom Protista to the literature in 1866), and gave it the name Magnosphaera planula. M. planula appeared in some ways to have characteristics intermediate between typical protists and multicellular organisms. It appeared to have different life stages: a ball-like colony of flagellated cells, and a stage of separate, amoeboid cells, joined presumably by the development of new colonies from the encystment of an individual amoeboid cell and repeated cell division. Haeckel would repeatedly refer in his publications over the next 30 years to $M$. planula as an important example of evolutionary grade illustrating the transition between single and multicellular life, or even, in some phylogenetic trees, as a representative of the 'Planula' or 'Blastaea' grade of ontogenetic development, and a fairly direct link between protists and his 'Gastraea' grade of early evolution in metazoans. The problem with this was that, with one dubious exception (ironically, the early radiolarian worker Parona), no one other than Haeckel ever claimed to have seen M. planula; Haeckel did not deposit specimens in his, or anyone else's collections, and attempts to re-collect this important species met with failure. Within just a few years after publication, some scientists began to doubt if Haeckel's description of $M$. planula was entirely accurate. Haeckel's taxonomic descriptions of other material had been questioned as well. H. J. Carter, a contemporary student of sponges, had, for example, already described Haeckel's sponge work 'as imaginative and incorrect as it is beautiful' (Carter 1871, quoted in Reynolds \& Hülsmann, 2008). While many scientists accepted the description of Haeckel, others were less sure. Bütschli, in particular, was sceptical and suggested that the organism was misclassified. Reynolds \& Hülsmann (2008), after reviewing the evidence, suspect that M. planula, in fact, never really existed. They suggest that it was an observational error, magnified into a complete, unique organism by Haeckel's inferring, based on his theoretical expectations, several transitions between a set of different biological forms in his samples that represented in reality several different, unrelated species of organism (true amoeba, possibly also detached sponge cells, and part of an invertebrate larva). That Haeckel did not question his observations, or attempt to reproduce them, is attributed, according to these authors, to Haeckel's 'desire to find the "missing link" between protists and metazoans [which] had a strong influence on the judgement of Haeckel and other professional zoologists' (Reynolds \& Hülsmann, 2008, p. 362).

\section{Rüst (1831-1916)}

David Rüst began his career as a medical doctor, but, after losing an eye in an accident, resigned from the military and established himself in private practice in Hannover. Palaeontology and botany (primarily succulents) were hobbies that he pursued on the side. Rüst published 10 papers on radiolarians (Radrefs database), including 4 larger papers (Rüst, 1885, 1888, 1892, 1898). Rüst's papers describe over 900 new species of fossil radiolarians from Mesozoic and even Palaeozoic rocks from Europe and North America, and some of the material was given to him by Haeckel. The quality of this material was quite variable. It included some well-preserved, free radiolarians, but much of it was studied only in thin section, leading to a large number of species descriptions and illustrations that are difficult to interpret. Another complication was the frequent use by Rüst of Haeckelian generic names that were based on Cenozoic material, and which today are considered to be not co-generic (Steiger, 1995). Rüst, although not the first to describe Mesozoic radiolarians (Zittel, 1876 and Pantanelli, 1880 preceded him), was certainly the most prolific. As most of Rüst's species come from older rocks, the IODP TNL cannot be used to evaluate the current impact of Rüst's taxonomy, although Steiger (1995) notes that of 67 species described from one locality, only 7 are in current use, and these were in fact unused for more than 50 years before being resurrected in the 1970s. Although Rüst took good care to deposit his materials in a major museum (the Bavarian State Collections in Munich), the collection was completely destroyed, along with the Museum, during World War II (Steiger, 1995, pers. comm. 2009). An attempt by Steiger (1995) to relocate and re-describe radiolarians from one of the more important European Jurassic localities was moderately successful, yielding new material that could serve for re-description for approximately half of the 67 species originally described from the locality. Similar studies have not been carried out for any of Rüst's other localities. 


\section{E. Stöhr}

Emile Stöhr held the position of Director of Mines in the Bavarian capital of Munich. Personal details are not known, though his death was reported in the Bulletin de la Société Géologique de France in 1882 (p. 297, meeting of 13 April 1882). Stöhr published only two papers on radiolarians, the first in 1878 in Italian but without much formal new taxonomy, the second in 1880 in German, in which he described 78 species and 4 new genera, many for spongy spumellarians, from Late Neogene (probably Messinian) material from Sicily. Eight of Stöhr's species are counted as valid in the TNL based on recent use. Lazarus et al. (2005) note that Stöhr's morphological descriptions for many of his spumellarian taxa are difficult to match to those used today. This uncertainty in the definition of his forms has led to later authors sometimes assigning his species to entirely different families. All of the species still considered valid have been revised by later authors. Stöhr did not indicate types or, if he had deposited material in a repository, attempts to trace such material by Lazarus et al. (2005) were unsuccessful. It is possible that his materials, if they existed, were lost along with Rüst's with the destruction of the Munich Natural History Museum collections during World War II.

\section{F. Dreyer (1866-?)}

Friedrich Dreyer studied under Haeckel in Jena and published only a few papers on radiolarians. These appeared mostly between 1889 and 1982 and presumably were derived from his doctoral thesis work (Die Theorie der Biokrystallisation in allgemeinen und de Skelettbildung der Polycystinen in besonderen. Jena, 1890). Only his 1889 and 1890 papers contain significant species descriptions. Dreyer explicitly states in the introduction to his 1889 work that his studies are an attempt to improve the 'naturalness' of the higher-level classification created by Haeckel. $\mathrm{He}$ also adds a plea to other workers not to attempt to modify Haeckel's classification except when there are good specific reasons to do so, since otherwise a form of taxonomic disaster (Unheil) could ensue. Dreyer's higher-level taxonomy attempted to unite very different forms based on the presumed homology of large pores in the shell, which he called pylomes. As a consequence to this theory he added 74 new species, 9 new genera, and 4 new subfamilies to Haeckel's classification. Unfortunately this pylome homology was based only on comparison of skeletons - Dreyer did not have any plankton specimens with protoplasm of his pylome taxa for study purposes. The fate of Dreyer's taxonomy is mixed. Some of his pylome definitions at the level of genus and species are still used (e.g. Sphaeropyle; S. langii) but most subsequent workers have not made use of his higher (subfamily) taxa, as they are, in the absence of additional biological data on homology, rather speculative and not much needed for the use of radiolarians in applied studies at the species level (Lazarus et al., 2005). The location of Dreyer's studied material is unknown: it was not found in Jena during searches for original Haeckel materials (Lazarus, 2000; Aita et al., 2009) and possibly was never explicitly deposited or marked as being type series. The original Challenger sediment samples on which Dreyer based many of his species (some were also based on Sicilian sediments similar to Stöhr's) are clearly indicated by Dreyer in his papers and these are still available in London. For this reason, Dreyer's generic names were preferred by Lazarus et al. (2005) to establish a better foundation for generic names in pylome-bearing spumellaria.

\section{H. Mast}

Heinrich Mast (personalia unknown) was a student of Haeckel and worked on part of the material (the Astrosphaeridae, a group of actinommids) collected by the German Tiefsee Expedition on the ship Valdivia. Mast followed the phylogenetic/evolutionary goals defined by Haeckel, and sought insights into the phylogeny of radiolarians in studying this group of actinommids, which he described in the introduction to his work as the 'most primitive, and apparently also oldest radiolarian forms' (Mast, 1910, p. 3). He created 4 new subfamilies based on numbers of shells, and 12 new genera, in addition to 64 new species. Of these, only one genus (Heteracantha, renamed as Anomalacantha by Loeblich \& Tappan (1961) as it was a junior homonym of multiple older uses), and two species are used in the TNL listing. Mast often had very little material available for any given form, which is also the case for other authors working with plankton material after an expedition. He indicates clearly not only which samples each species description is based on, but also the approximate number of specimens. About half of his species are based on fewer than 10 specimens (not all complete), and many are based on only a few, or even just one or two specimens. Having so few specimens meant there was little opportunity to evaluate within-species variation, or the possibility that a new species might be just a variant of another. Lastly, many of the species in this group are large and fragile. They are usually present only in broken form in sediments, and thus are only rarely studied in fossil form. Mast carried out his research at the (present) University of Stuttgart; the location of his original materials has not been determined.

\section{A. W. K. Popofsky}

Arthur Willy Karl Popofsky studied under Brandt in Kiel, and his first publication was his doctoral dissertation work on the Acantharia, based on material of the German Plankton Expedition of 1889 (Popofsky, 1904, 1906). Popofsky, like Rüst, was not employed in a professional university position for most of his career. He carried out the bulk of his radiolarian studies outside of his regular duties as a teacher, and later (c. 1920-1940) director, in the Guerke-Oberreale school in Magdeburg. [Precise dates and personalia for Popofsky are not known, as the city archives and school museum of Magdeburg were, when researching this paper, under renovation and not accessible; and most school documents were in any case destroyed during World War II $(\mathrm{H}$. Pellmann, Magdeburg Natural History Museum, pers. comm. 2012)]. These schools provided a nine-year education with a focus on natural sciences and modern languages, and awarded diplomas that qualified graduates to study these subjects at university. The school was eventually closed in 2008, and information on its history, including some on director Popofsky, was given in a review address by Brücher (2008). Popofsky is mentioned by Brücher for his well-known drawings of animals, and for his opposition - as long as it was legally allowed - to the posting of Nazi materials in the school building.

Popofsky published approximately a dozen papers on radiolarians. After his dissertation, all but one minor later paper, and a late published contribution to the Plankton Expedition descriptions of Phaeodaria (Coelodendridae; Popofsky, 1926), were based on 
material collected by the German South Polar expedition of 19011903, and most published as part of the official expedition reports. The South Polar expedition was led by Drygalski using the research ship Gauss. Popofsky is not listed as one of the small number of scientists on the expedition itself and so presumably was asked, as Haeckel had been earlier for the Challenger expedition, to prepare a report after the ship returned home. Several of Popofsky's reports were of near-monographic length, with the papers of 1908, 1912 and 1913 containing the majority of his polycystine species descriptions. The TNL lists 188 polycystine species described by Popofsky, below only Ehrenberg among the early German authors and among the top 10 authors of early names, regardless of nationality. Popofsky's species descriptions and illustrations were generally of a high quality and are much more detailed than the very brief descriptions of earlier workers, such as Ehrenberg and Haeckel. Although he did not explicitly designate type specimens, he clearly indicated the samples which he used as the basis for his description. Popofsky often, however, used only a very few specimens, or even one specimen, to define new species. The limitations on material were imposed by the amounts made available to him by the collecting work of the Gauss expedition, and could not be improved easily. However, he did not, as would occur in more modern studies, choose to describe these more limited materials in open nomenclature, but gave them formal names.

Popofsky continued the 'evolutionary' tradition established by Haeckel, and discussed possible evolutionary series and transformations of characters. He cited work by Rüst on Palaeozoic radiolarians in trying to determine which characters were ancestral, favouring 'double' triple spicules similar to the nassellarian primary spicules as the ancestral state, v. alternatives with a single 4-spicule arrangement, as proposed by Dreyer (Popofsky, 1912). $\mathrm{He}$ also discussed the apparent artificiality of some of Haeckel's families, thus in some cases simplifying the system created by Haeckel. For example, Mast had, from series of specimens in plankton material, inferred the ontogenetic development of spines. Popofsky used this new biological knowledge to suggest that Liosphaeridae, one of Haeckel's 5 families in the Sphaeroidea, was artificial and the genera in this family should be reassigned to the remaining 4 families. Popofsky, none the less, introduced 29 new generic names, according to the Radworld genus database. Most of these appear to be little used today. The current locations of Popofsky's materials are unknown. The Guerke school building in Magdeburg was very heavily damaged in World War II and any material there would presumably have been destroyed unless it had been evacuated earlier. A large part of the original collections of the Süd-Polar expedition were stored in the Meereskunde (Oceanography) Institute in the centre of Berlin. This building too was destroyed in the war. Some material from this expedition is also held in the Museum für Naturkunde in Berlin, but to date no trace of any material specifically used by Popofsky has been seen.

\section{CURRENT STATUS OF EARLY WORKERS' SPECIES NAMES}

A summary of the current status of species names by early workers is given in Table 1. This summary is restricted to German authors with at least 30 total names; and for comparison to other early radiolarian workers, though only those with at least 60 known names, plus a selection of the more prolific modern phase workers. Table 1 shows, as expected, a general correspondence between the number of species published by early workers and the number of species considered valid today. However, the majority of published species from early work, regardless of author, are not recognized today as valid they are either explicitly considered synonyms of other species, or (the large majority) simply have never been used in modern research. Since for the most part, modern deep-sea sediment research is based very much on the same material as studied by these early authors (deep-sea sediments or formerly pelagic Cenozoic sediments exposed in outcrop on land) this can be explained only by considering the unused species descriptions as 'nomen dubia', e.g. species whose original descriptions cannot be assigned with any reliability to any known actual material, e.g. cannot be found in deep-sea sediments. There are a couple qualifications that must be made. First, a fraction of the names in the TNL that are listed as synonyms are not validly published names but spelling errors, name variants and the like. For the German authors discussed above, variant names were explicitly excluded by additional searches and hand editing, which if not perfect, provides a very close approximation $(1-2 \%)$ to the correct number. The percent 'non-valid' number for the other authors, however, is somewhat inflated, generally by $c .10-20 \%$, although this taxonomic 'noise' is presumably more or less the same across authors. Also, for a few of the authors, the discrepancy can be explained more or less completely by their study of material not common in the deep-sea drilling literature - Mesozoic, or in the case of Deflandre, even Palaeozoic. Excluding these authors, and taking due consideration of the inflating effect of variant names, however, does not alter the conclusion that the majority of species names published by these early taxonomists and, in some cases, the large majority, have had no impact or usage in modern research. There are also differences between authors, the most obvious being the much larger discrepancy in the ratios of numbers of published species (nearly $\times 7$ ) and number of currently valid species (less than $\times 2$ ) between Haeckel and Ehrenberg.

Figure 5 summarizes the information in Table 1, showing the relationship between number of species described by each author and the percent of these used in modern deep-sea sediment research (Group 1). Authors in Table 1 who published primarily on Mesozoic or even Palaeozoic taxa are plotted but with a different symbol (Group 2) as species of these authors are likely not to be well represented by deep-sea sediment studies. If the a-priori removal of Meso/Palaeozoic authors is accepted, the remaining data fall into three distinct bands. The majority of authors have current usage values between $c .5$ and $25 \%$, with a trend towards larger percentage usage among authors with larger numbers of species. A small group of 4 authors (Vinassa de Regny, Principi, Mast, Haeckel) have low percentage modern usage values (c. 5\% or less), while one author (Jørgensen) forms a distinct outlier with very high modern usage of over $35 \%$.

\section{DISCUSSION}

Studies of radiolarians by early German workers, such as Ehrenberg, Haeckel, Rüst and Popofsky, laid the foundation for all future work with this group of organisms, both living and fossil. The basic framework of higher-level taxonomy, a broad survey of cell biology and many of the genus and species names still 


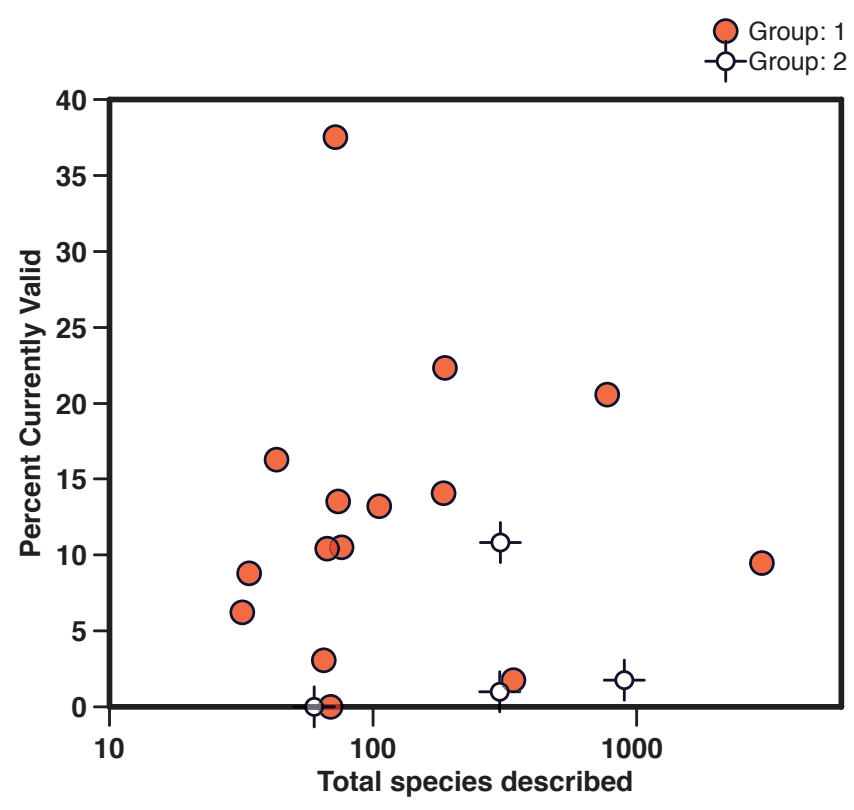

Fig. 5. Statistical summary of authors' species taxonomy v. current use. Each dot represents one author from Table 1. Group 2 are authors who primarily published on older materials and whose current usage cannot be estimated from the TNL database used in this paper.

in use are the main elements of this legacy. Despite considerable effort, these early workers did not develop a detailed modern understanding of the distribution of radiolarians either as living organisms in the ocean, or as a biostratigraphically important group of fossils, but these limitations can be explained by the then relatively immature state of knowledge in physical and biological oceanography, and in historical geology. The work of this early, German-dominated group of scientists would be superseded only with the development of modern radiolarian research by Riedel and others in the second half of the twentieth century.

Beyond these general statements, several other conclusions can be drawn from this review of early radiolarian taxonomy and taxonomists. These are of a more nuanced nature and consider not only the success of prior work, but also those aspects where it was not. Several factors appear to have been important in determining the degree to which an early worker's publications contributed to the long-term development of the field, particularly the success of their species-level taxonomy. The importance of priority in description is one. Ehrenberg's species descriptions, being the oldest, have the advantage of having priority, and this is one reason for the relatively high percentage of his species and genera names still in use. Another is the importance of what are generally considered to be good taxonomic practice: well-preserved material, adequate numbers of specimens, detailed description and accurate illustrations. Authors who largely adhered to these practices have had their taxonomic work survive better than those who did not unlike the other authors of Cenozoic-Recent material considered here, Vinassa de Regny and Principi's works were based on relatively poorly preserved land materials and both the descriptions and illustrations were not comparable to those of most other workers, such as Ehrenberg and Popofsky, who had access to better preserved material, and whose illustrations were more detailed and accurate. Also important is having well-documented collections, and properly labelled type specimens. Through no fault of their own, the majority of early authors' collections, assuming they once-existed, have since been lost, usually during the destruction caused by World War II. Only Ehrenberg's and Jörgensen's have survived, and these two authors have the two highest percentages of still used species of all those considered. Ehrenberg's collection has been re-described only very recently, but, as his specimens are re-evaluated in future individual taxonomic studies, the use of his species names is likely to increase. Jörgensen's material was redescribed in a highly accessible form (the DSDP Leg 38 volume) early in the history of deep-sea drilling by Bjørklund (1976), which almost certainly contributed to the greater use of Jörgensen's taxonomic names. Sometimes the reasons for the apparent success or failure of an author's taxonomic work are less clear. Mast's study is an example of this - reasonably well described and illustrated, albeit often on only a few specimens per species, almost none of his taxa are considered in this study to be currently in use. This probably in part reflects the restriction of Mast's taxonomy to a group of actinommids that are normally poorly preserved in sediments, and thus rarely used in fossil studies. Although the TNL database does include species thought to be valid living forms, the number of plankton papers used to create the list of living species so far is much less than that used to compile the fossil forms, and there may be to some extent a sampling bias in the diversity list, e.g. some more of Mast's species may, indeed, be currently in use, just not recorded yet in the TNL. There may even be some justification in believing that plankton studies themselves are biased to some extent towards the study of those forms that are also found as fossils. These arguments apply as well to most of Müller's species, which belonged primarily to the actinommids, collosphaerids or collodarians.

One of the more interesting results from the above analyses is the apparent correlation between numbers of species described by an author and the success of the author's species in subsequent use. The correlation - it should be stressed - exists only if one accepts the a-priori argument to exclude workers on Mesozoic or older material, and also only if one accepts the division of the workers into three categories (low-use group, Jörgensen, the others). Even if we can accept these conditions, it is not immediately clear why authors with many published species should also have more species still in use. Although pure speculation, possibly the more prolific authors' publications have simply been more frequently consulted by modern workers, who needed to identify material but had relatively little time for exhaustive searches of the complete literature. Such a situation would tend to steer modern workers to a small number of works which could most quickly provide a reasonable chance of providing a suitable description and name. If this is true, the effect might gradually disappear once comprehensive taxonomic catalogues become available for radiolarians, for in such references all taxonomic works are equally accessible.

The last issue to be discussed here is the unusual fate of Haeckel's taxonomy. Given the above arguments, Haeckel's beautiful, professionally created illustrations, his status as the most prolific source of taxonomic names, and his use of extensive, well-preserved material, including both plankton and sediments, should have secured for his species taxonomy a very high rate of subsequent use. Instead, the large majority of Haeckel's species names are not used, and he has among the lowest percentages of any author, regardless of how many species were 
published. This is a major discrepancy that needs explaining. Partially, the explanations are similar to those for other authors. While Haeckel's published illustrations are visually excellent, as noted earlier, not all are thought to be accurate. And, despite 140 plates, by no means all of his new species were illustrated: approximately a third of the species descriptions on any given page in Haeckel (1887) do not have a plate citation, and Suzuki's database notes in the TNL record $>1300$ names published by Haeckel without illustrations. Many of Haeckel's species descriptions were also very brief - just a couple of sentences. These problems clearly are major contributors to the limited use of his species in modern research.

Another key factor appears to be Haeckel's development of an elaborate, higher-level taxonomy and the role it played in the development of species-level taxonomy. As noted above, imposing an artificial higher-level classification on a group of organisms can lead to a forced duplication of taxonomic units at lower levels and the proliferation of numerous redundant lower-level taxa names. The decision as to whether or not one has enough information to determine 'natural' higher-level taxonomic units is difficult to make, and Haeckel is certainly not the only taxonomist to misjudge the adequacy of the information available. Modern radiolarian researchers still have very different opinions on this issue. Some have continued to elaborate new higher-level classifications of radiolarians, including hypothesized transformation series for different character states (e.g. Petrushevskaya, 1971; Afanasieva et al., 2005) while other workers have confined their higher-level taxonomy to a relatively small number of families based on clearly distinct Baupläne (e.g. Riedel, 1971). Yet, when compared to other groups of organisms, it is clear that the amount of biological knowledge of the sort used for higher-level taxonomy that is available to us for radiolarians is still very meagre. We do not have anything but indirect evidence for the ontogenetic development of the radiolarian shell, we have virtually no knowledge of the functional significance of individual shell characters, and we have not yet resolved the phylogenetic status of the major clades of radiolarians and other groups that may be related to them (Polycystinea, Acantharia, Phaeodaria, Foraminifera, etc.). Nor, despite an excellent fossil record for the Polycystinea, do we have much evidence for the time of origin or probable ancestral taxon for most polycystine families. It is most likely that molecular methods will soon provide new insight into radiolarian phylogeny, but until then, on general biological arguments, we remain in a very poor position to attempt to develop a detailed higher-level taxonomy for the group. This problem was, of course, even more acute in earlier studies of radiolarians.

The problem of not having enough information to create a robust higher-level taxonomy existed for both Ehrenberg and Haeckel, but they responded quite differently. While Ehrenberg (like Riedel and some others today) largely eschewed higher taxa, except for a minimally adequate number of obvious, high-level groupings, Haeckel imposed an extensive, and largely artificial classification on his material, generating numerous duplicate lower-level categories, including species, in the process. These duplicated species have led to endless confusion among subsequent workers and, in particular, have led to an unusually large percentage of Haeckel's named species being ignored as redundant or meaningless.

Although it enters the realm of speculation, an obvious question is why Haeckel decided to develop his taxonomy as he did, since workers both before (Ehrenberg) and after (Riedel) him did not find it necessary to do so. What we know of Haeckel is suggestive, and the case of Magnosphaera planula seems to define the key points: theory unduly influencing observation, imaginative illustrations based only partially on actual observation, uncritical acceptance of observations that support theoretical goals, failure to document with actual material the published new taxa. Haeckel's taxonomy, in particular the Challenger radiolarian monograph, is a great achievement and contribution to science, but appears to have been affected by these same problems. Haeckel's desire to document and describe evolution in everything he studied led him to impose an unjustifiable taxonomic system on his materials; he did not adequately document his taxonomy with preserved specimens, and his illustrations of species are certainly beautiful, but sometimes missing and partially suspect. All this has resulted in a largely ignored species-level taxonomic legacy.

It is a capital mistake to theorize in advance of the facts. Invariably, you end up twisting facts to suit theories, instead of theories to suit facts ('Sherlock Holmes', by A. Conan Doyle).

\section{ACKNOWLEDGEMENTS}

The author wishes to thank his colleagues N. Suzuki, J.-P. Caulet, A. Sanfilippo and J. Dolven for their willingness to share their unpublished databases and taxonomic listings; P. Diver for patience and programming support; and Hui Luo and J. Aitchison for supporting the symposium at the 12th Interrad Congress in Nanjing, from which this paper grew. J. Gregory and A. Lord are thanked for review and editing the manuscript.

\section{Manuscript received 26 November 2012 Manuscript accepted 26 November 2012}

Scientific Editing by F. John Gregory

\section{REFERENCES}

Afanasieva, M.S., Amon, E.O., Agarkov, Y.V. \& Boltovskoy, D. 2005. Radiolarians in the Geological Record. Paleontological Journal, 39: 135-392.

Aita, Y., Suzuki, N., Ogane, K., Sakai, T., Lazarus, D., Young, J. \& Tanimura, Y. 2009. Haeckel Radiolaria Collection and the H.M.S. Challenger Plankton Collection. In Tanimura, Y. \& Aita, Y. (Eds), Reexamination of the Haeckel and Ehrenberg Microfossil Collections as a Historical and Scientific Legacy. Japan National Museum of Nature and Science, Tokyo, Monograph, 40: 35-46.

Baker, D.B. 1997. C.G. Ehrenberg and W.F. Hemprich's travels, 1820-1825, and the insecta of the Symbolae Physicae. Deutsche Entomologische Zeitschrift, 44: 165-202.

Bjørklund, K.R. 1976. Radiolaria from the Norwegian Sea, Leg 38 of the Deep Sea Drilling Project. In Talwani, M., Udintsev, G. ET AL. (Eds), Initial Reports of the Deep Sea Drilling Project. US Government Printing Office, Washington, DC, 1101-1168.

Boltovskoy, D., Kling, S.A., Takahashi, K. \& Bjørklund, K. 2010. World atlas of distribution of living radiolaria. Palaeontologia Electronica, 13(3).

Brücher, B. 2008. Rede zur Feier der Enthüllung einer Gedenktafel am 25.10.2008 zur 140-jährigen Wiederkehr der Gründung der Guericke-Schule Magdeburg, http://www.ovg-jubilaeumstafel.de/ Festrede_140Jahre_OvG.pdf

Dreyer, F. 1889. Morphologischen Radiolarienstudien. 1. Die Pylombildungen in vergleichend-anatomischer und entwicklungs geschichtlicher Beziehung bei Radiolarien und bei Protisten uberhaupt nebst System und Beschreibung neuer und der bis jetzt bekannten pylomatischen Spumellarien. Jenaische Zeitschrift fur Naturwissenschaft, 23: 1-138. 
Dreyer, F. 1890. Die Tripoli von Caltanisetta (Steinbruch Gessolungo) auf Sizilien. Jenaische Zeitschrift fur Naturwissenschaft, 24: 1-79.

Ehrenberg, C.G. 1839. Uber die Bildung der Kreidefelsen und des Kreidemergels durch unsichtbare Organismen. Königliche Akademie der Wissenschaften zu Berlin, Abhandlungen. Jahre 1838: 59-147.

Ehrenberg, C. 1905. Unser Elternhaus. Verlag Max Schildberger, Berlin, $224 \mathrm{pp}$.

Gasman, D. 2004. The Scientific Origins of National Socialism (new edn) Transaction, New Brunswick, 208pp.

Haeckel, E. 1862. Die Radiolarien (Rhizopoda Radiaria). Eine monographie. Reimer, Berlin, xiv $+572 p p$.

Haeckel, E. 1881. Entwurf eines Radiolarien-Systems auf Grund von Studien der Challenger-Radiolarien [Basis for a radiolarian classification from the study of Radiolaria of the Challenger collection]. Jenaische Zeitschrift fur Naturwissenschaft, 15: 418-472.

Haeckel, E. 1887. Report on the Radiolaria collected by H.M.S. Challenger during the years 1873-1876. Report on the Scientific Results of the Voyage of the H.M.S. Challenger, Zoology, 18: clxxxviii + 1-1803.

Jahn, R. 1998. C.G. Ehrenberg: The man and his contribution to botanical science. In Williams, D.M. \& Huxley, R. (Eds), Christian Gottfried Ehrenburg [sic]: The Man and his Legacy. Linnean Society, London, 14-29.

Kling, S.A. 1978. Radiolaria. In Haq, B.U. \& Boersma, A. (Eds), Introduction to Marine Micropaleontology. Elsevier Scientific, New York, 203-244.

Lazarus, D.B. 1994. The Neptune Project - a marine micropaleontology database. Mathematical Geology, 26: 817-832.

Lazarus, D.B. 1998. The Ehrenberg Collection and its curation. In D.M., Williams, D.M. \& Huxley, R. (Eds), Christian Gottfried Ehrenburg [sic] (1795-1876): The Man and his Legacy. Linnean Society, London, 31-48.

Lazarus, D.B. 2000. Ehrenberg, Haeckel and the problem of types: status report. In Carter, E.S., Whalen, P., Noble, P.J. \& Crafford, A.E.J. (Eds), Ninth Meeting International Association of Radiolarian Paleontologists, Department of Geological Sciences, University of Nevada, Reno, 46.

Lazarus, D. 2005. A brief review of radiolarian research. Paläontologische Zeitschrift, 79: 183-200.

Lazarus, D. 2006. The Micropaleontological Reference Centers network. Scientific Drilling, 3: 46-49.

Lazarus, D.B. \& Jahn, R. 1998. Using the Ehrenberg Collection. Diatom Research, 13: 273-291.

Lazarus, D. \& Suzuki, N. 2009. Introduction to the Reexamination of the Haeckel and Ehrenberg Radiolarian Collections. In Tanimura, Y. \& Aita, Y. (Eds), Reexamination of the Haeckel and Ehrenberg Microfossil Collections as a Historical and Scientific Legacy. Japan National Museum of Nature and Science, Tokyo, Monograph, 40: 23-34.

Lazarus, D., Faust, K. \& Popova-Goll, I. 2005. New species of prunoid radiolarians from the Antarctic Neogene. Journal of Micropalaeontology, 24: 97-121.

Lazarus, D., Dolven, J.K. \& Sanfilippo, A. 2011. Polycystinea. WoRMS, www.biodiversity.org

Lazarus, D., Suzuki, N., Diver, P., Caulet, J.-P., Dolven, J.K. \& Sanfilippo, A. 2012. A first general list of evaluated, annotated Cenozoic and Mesozoic radiolarian names. In O'Dogherty, L. (Ed.), Abstracts and Program, Interrad 13. Cadiz, Spain.

Loeblich, A.R. \& Tappan, H. 1961. Remarks on the systematics of the Sarkodina (Protozoa), renamed homonyms and new and validated genera. Proceedings of the Biological Society of Washington, 74: 213-234.

Lombari, G. \& Lazarus, D. 1988. Neogene cycladophorid radiolarians from North Atlantic, Antarctic, and North Pacific deep-sea sediments. Micropaleontology, 34: 97-135.

Mast, H. 1910. Die Astrophaeriden der Deutschen Tiefsee-Expedition, Band XIX. Inaugural-Dissertation zur Erlangung der Doktorwurde, Universitat Tubingen, 1-68.

Meyen, F.J.F. 1834. Uber das Leuchten des Meeres und Beschreibung einiger Polypen und anderer niederer Tiere [On starfish and a description of some polyps and other inferior animals]. Beiträge zur Zoologie, gesammelt auf einer Reise um die Erde. Nova act a Academiae Caesareae Leopoldino Carolinae germanicae naturae curiosorum, 125-216.

Moltrecht, C. 1995. Christian Gottfried Ehrenberg: Leben und Werk eines Delitzscher Naturforschers. Druck- und Verlagshaus Delitzsch GmbH, Delitzsch, 32pp.

Müller, J. 1855. Uber Sphaerozoum und Thalassicolla. Königliche Preussische Akademie der Wissenschaften zu Berlin, Bericht. Jahre 1855: 229-253.

Müller, J. 1856. Uber die Thalassicollen, Polycystinen und Acanthometren des Mittelmeeres [The Thalassicolla, Polycystina, and Acanthometra from the Mediterranean Sea]. Königliche Preussischen Akademie der Wissenschaften zu Berlin, Monatsbericht. Jahre 1856: 474-503.

Müller, J. 1859. Uber die Thalassicollen, Polycystinen und Acanthometren des Mittelmeeres. Königliche Preussische Akademie der Wissenschaften zu Berlin, Abhandlungen. Jahre 1858: 1-62.

Nigrini, C. 1977. Tropical Cenozoic Artostrobiidae (Radiolaria). Micropaleontology, 23: 241-269.

Ogane, K., Suzuki, N., Aita, Y., Sakai, T. \& Lazarus, D. 2009. Ehrenberg's Neogene radiolarian collections from Barbados. In Tanimura, Y. \& Aita, Y. (Eds), Reexamination of the Haeckel and Ehrenberg Microfossil Collections as a Historical and Scientific Legacy. Japan National Museum of Nature and Science, Tokyo, Monograph, 40: 97-106.

Pantanelli, D. 1880. I diaspri della Toscana e i loro fossili. Atti della reale Accademia nazionale dei Lincei, Memorie della Classe di Scienze fisiche, matematiche e naturali, 8: 35-66.

Petrushevskaya, M.G. 1971. Radiolyarii Nassellaria v planktone mirovogo okeana [Radiolarians of the Ocean]. Akademiya nauk SSSR, Zoologicheskii Institut, Issledovaniya Fauny Morei, 9: 294.

Popofsky, A. 1904. Die Acantharia der Plankton-Expedition. Teil 1: Acanthometra. Ergebnisse der Plankton-Expedition der HumboldtStiftung, 3 L: 1-160.

Popofsky, A. 1906. Die Acantharia der Plankton-Expedition Teil II: Acanthophracta. Ergebnisse der Plankton-Expedition der HumboldtStiftung, III L f b, 1-160.

Popofsky, A. 1908. Die Radiolarien der Antarktis (mit Ausnahme der Tripyleen). In Drygalski, E. (Ed.), Deutsche Südpolar-Expedition 19011903 (Zoologie 2), X: 184-305.

Popofsky, A. 1912. Die Sphaerellarien des Warmwassergebietes. In Drygalski, E. (Ed.), Deutsche Sudpolar-Expedition, 1901-1903 (Zoologie 5), XIII: 73-159.

Popofsky, A. 1913. Die Nassellarien des Warmwassergebietes. In Drygalski, E. (Ed.), Deutsche Sudpolar-Expedition, 1901-1903 (Zoologie 6), XIV: 217-416.

Popofsky, A. 1926. Die Tripyleen Radiolarien der Plankton-Expedition. Coelodendridae. Ergebnisse der Plankton-Expedition der HumboldtStiftung, III L. h. 13: 1-101.

Popper, K. 1945. The Open Society and its Enemies. Routledge, London, 2 vols.

Reynolds, A. \& Hülsmann, N. 2008. Ernst Haeckel's discovery of Magosphaera planula: A vestige of metazoan origins? History and Philosophy of the Life Sciences, 30: 339-386.

Richards, R.J. 2008. The Tragic Sense of Life: Ernst Haeckel and the Struggle Over Evolutionary Thought. University of Chicago Press, Chicago, 512pp.

Riedel, W.R. 1967. Subclass Radiolaria. In Harland, W.B., Holland, C.H. ET AL. (Eds), The Fossil Record. A symposium with documentation. Geological Society, London, 291-298.

Riedel, W.R. 1971. Systematic classification of polycystine Radiolaria. In Funnell, B.M. \& Riedel, W.R. (Eds), The Micropalaeontology of Oceans. Cambridge University Press, Cambridge, 649-661.

Rüst, D. 1885. Uber fossile Radiolarien aus Schichten des Jura. Jenaische Zeitschrift fur Naturwissenschaft, 18: 40-44.

Rüst, D. 1888. Beiträge zur Kenntniss der fossilen Radiolarien aus Gesteinen der Kreide. Palaeontographica, 34: 181-213.

Rüst, D. 1892. Beiträge zur Kenntnis der fossilen Radiolarien aus Gesteinen der Trias und der paläozoischen Schichten. Palaeontographica, 38: 107-179. 
Rüst, D. 1898. Neue Beiträge zur Kenntniss der Fossilen Radiolarien aus Gesteinen des Jura und der Kreide. Palaeontographica, 45: 1-67.

Sakai, T., Suzuki, N., Ogane, K. et al. 2009. Haeckel's Messina radiolarian collection housed in Ernst-Haeckel-Haus. In Tanimura, Y. \& Aita, Y. (Eds), Reexamination of the Haeckel and Ehrenberg Microfossil Collections as a Historical and Scientific Legacy. Japan National Museum of Nature and Science, Tokyo, Monograph, 40: 47-54.

Sanfilippo, A. \& Caulet, J.-P. 1998. Taxonomy and evolution of Paleogene Antarctic and tropical Lophocyrtid radiolarians. Micropaleontology, 44: $1-43$.

Sanfilippo, A., Westberg-Smith, M.J. \& Riedel, W.R. 1985. Cenozoic radiolaria. In Bolli, H.M., Saunders, J.B. \& Perch-Nielsen, K. (Eds), Plankton Stratigraphy. Cambridge University Press, Cambridge, 631-712.

Scamardella, J.M. 1999. Not plants or animals: a brief history of the origin of Kingdoms Protozoa, Protista and Protoctista. International Microbiology, 2: 207-216.

Schwann, T. 1839. Mikroskopische Untersuchungen über die Übereinstimmung in der Struktur und dem Wachstum der Thiere und Pflanzen. Berlin.

Spencer-Cervato, C. 1999. The Cenozoic deep sea microfossil record: explorations of the DSDP/ODP sample set using the Neptune database. Palaeontologica Electronica, 2.

Steiger, T. 1995. Rüst's radiolarians from Urschlau (Late Jurassic, Chiemgau Alps, Bavaria). Geologisch-Paläontologische Mitteilungen, Innsbruck, 20: 407-435.

Stöhr, E. 1878. Sulla posizione geologica del tufo e del tripoli nella zona solfifera di Sicilia. Bollettino Reale Comitato Geologico d'Italia, 9: $498-519$.
Stöhr, E. 1880. Die Radiolarienfauna der Tripoli von Grotte, Provinz Girgenti in Sicilien [The radiolarian fauna of the Tripoli of Grotte, Girenti Province, Sicily]. Palaeontographica, 26: 71-124.

Suzuki, N. 2009. Radiolarian studies by Christian Gottfried Ehrenberg (17951876) and value of his species as type species of genera. In Tanimura, Y. \& Aita, Y. (Eds), Reexamination of the Haeckel and Ehrenberg Microfossil Collections as a Historical and Scientific Legacy. Japan National Museum of Nature and Science, Tokyo, Monograph, 40: 55-70.

Suzuki, N., Lazarus, D., Ogane, K., Aita, Y. \& Sakai, T. 2009a. General results of Reexamination of Ehrenberg's radiolarian collections: With instructions on efficient methods to find microfossils from the collection. In Tanimura, Y. \& Aita, Y. (Eds), Reexamination of the Haeckel and Ehrenberg Microfossil Collections as a Historical and Scientific Legacy. Japan National Museum of Nature and Science, Tokyo, Monograph, 40: 71-86 + appendices.

Suzuki, N., Ogane, K., Aita, Y., Sakai, T. \& Lazarus, D. $2009 b$. Reexamination of Ehrenberg's Neogene radiolarian collections and its impact on taxonomic stability. In Tanimura, Y. \& Aita, Y. (Eds), Reexamination of the Haeckel and Ehrenberg Microfossil Collections as a Historical and Scientific Legacy. Japan National Museum of Nature and Science, Tokyo, Monograph, 40: 87-96.

Tanimura, Y. \& Aita, Y. (Eds) 2009. Joint Haeckel and Ehrenberg Project: Reexamination of the Haeckel and Ehrenberg Microfossil Collections as a Historical and Scientific Legacy. Japan National Museum of Nature and Science, Tokyo, Monograph, 40: 1-106 + appendices.

Zittel, K.A. 1876. Ueber einige fossile Radiolarien aus der norddeutschen Kreiden. Zeitschrift der deutschen geologischen Gesellschaft, 28: 75-87. 


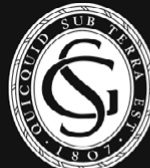

The

Geological

Society

serving science $\mathcal{E}$ profession

New and Recent Publications in the Rock-Forming Minerals series from the Geological Society Publishing House

\section{Rock-Forming Minerals (Second Edition):}

Complete set of 11 volumes

Rock-Forming Minerals is an essential reference work for professionals, researchers and postgraduate students in Earth sciences and related fields in chemistry, physics, engineering, environmental and soil sciences.
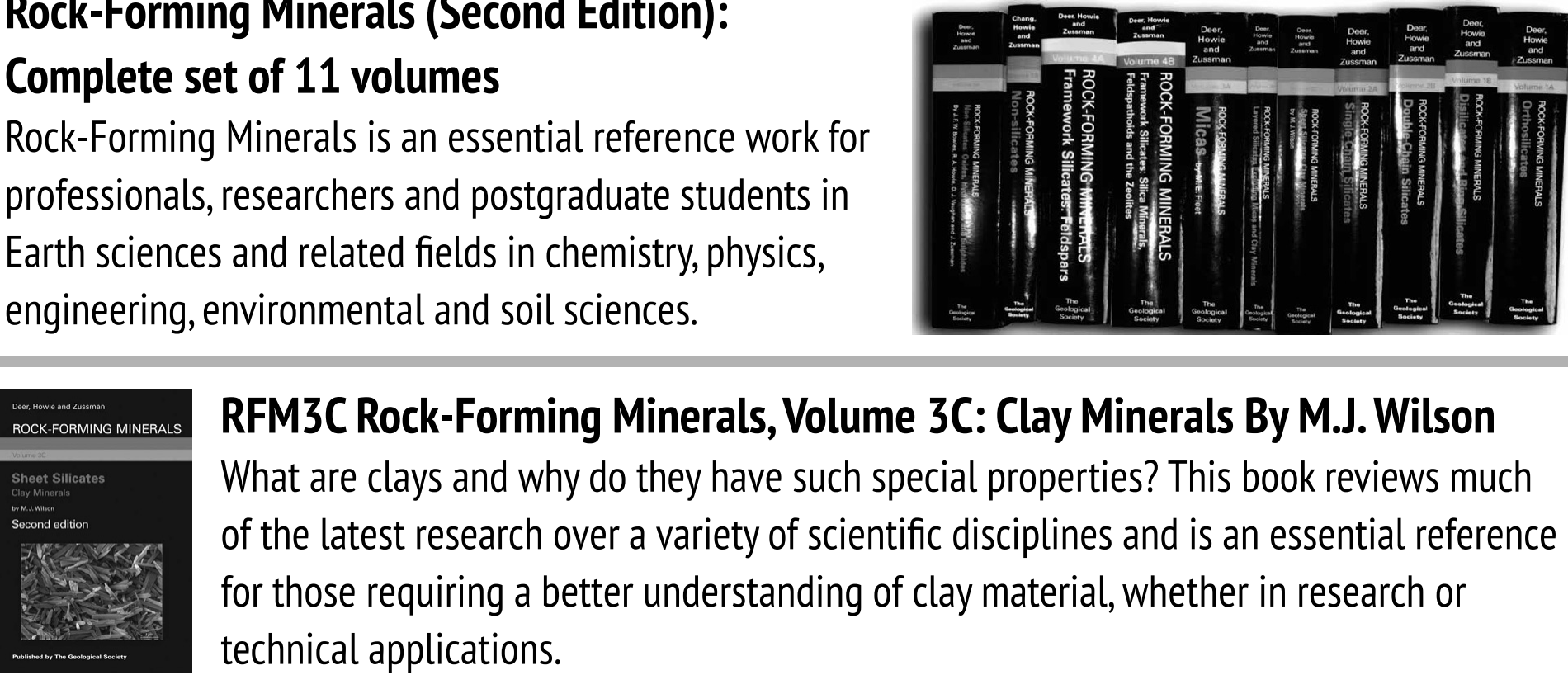

\section{RFM3C Rock-Forming Minerals, Volume 3C: Clay Minerals By M.J. Wilson}

What are clays and why do they have such special properties? This book reviews much of the latest research over a variety of scientific disciplines and is an essential reference for those requiring a better understanding of clay material, whether in research or technical applications.

\section{For full details see the Online Bookshop www.geolsoc.org.uk/bookshop}

Other titles in the series include...

RFM1A Rock Forming Minerals, Volume 1A: Orthosilicates

By W.A. Deer, R.A. Howie and J. Zussman

RFM1B Rock Forming Minerals, Volume 1B: Disilicates \& Ring

Silicates By W.A. Deer, R.A. Howie and J. Zussman

RFM2A Rock Forming Minerals, Volume 2A: Single-Chain Silicates

By W.A. Deer, R.A. Howie and J. Zussman

RFM2B Rock Forming Minerals, Volume 2B: Double-Chain Silicates By W.A. Deer, R.A. Howie and J. Zussman

RFM3A Rock Forming Minerals, Volume 3A: Micas By M.E. Fleet RFM3B Rock-Forming Minerals, Volume 3B: Layered Silicates: Excluding Micas and Clay Minerals By W.A. Deer, R.A. Howie and J. Zussman
RFM4A Rock Forming Minerals, Volume 4A: Framework Silicates: Feldspars By W.A. Deer, R.A. Howie \& J. Zussman

RFM4B Rock Forming Minerals, Volume 4B: Framework Silicates: Silica Minerals, Feldspathoids and the Zeolites By W.A. Deer, R.A. Howie, W.S. Wise and J. Zussman

RFM5A Rock-Forming Minerals, Volume 5A: Non-Silicates: Oxides, Hydroxides and Sulphides By J.F.W. Bowles, R.A. Howie, D.J. Vaughan and J. Zussman

RFM5B Rock Forming Minerals, Volume 5B: Non-Silicates:

Sulphates, Carbonates, Phosphates and Halides By L.L.Y. Chang, R.A. Howie and J. Zussman 